Research Report No. 4/2009

\title{
Constitution and Strategy: Understanding Canadian Power in the World
}

Irvin Studin

Follow this and additional works at: http:/ / digitalcommons.osgoode.yorku.ca/clpe

\section{Recommended Citation}

Studin, Irvin, "Constitution and Strategy: Understanding Canadian Power in the World" (2009). Comparative Research in Law \& Political Economy. Research Paper No. 4/2009.

http://digitalcommons.osgoode.yorku.ca/clpe/119 


\section{Comparative Research in Law \& Political Economy}

\section{Irvin Studin}

Constitution and Strategy: Understanding Canadian Power in the World

EDTORS: Peer Zumbansen (Osgoode Hall Law School, Toronto, Director, Comparative Research in Law and Political Economy, York University), J ohn W. Cioffi (University of California at Riverside), Lindsay Krauss (Osgoode Hall Law School, Toronto, Production Editor) 

CLPE Research Paper 04/2009

Vol. 05 No. 01 (2009)

\title{
Irvin Studin
}

\section{CONSTITUTION AND STRATEGY: UNDERSTANDING CANADIAN POWER IN THE WORLD}

\begin{abstract}
In this article, Irvin Studin provides a wide-ranging audit of Canada's Constitution, broadly defined, to distill an original picture of Canadian strategic power in the world. Whereas Canadian constitutional scholarship and jurisprudence are typically rooted in considerations of federalism and Charter rights, this article attempts to usher in a 'third school' of Canadian constitutional discourse exercised by the relationship between the Constitution and strategy--that is, the ways in which the Constitution explains and informs the federal state's capacity to pursue strategic interests in the world. The said audit focuses on the constitutional treatment of the diplomatic and military instruments of the Canadian state, as well as the constitutional treatment of key 'factors of strategic power' like executive efficiency, natural resources, the economy and the national population--factors of power that impact the potency of the diplomatic and military instruments. The audit centres around what Studin calls Canada's Strategic Constitution, and issues in a determination that while Canada was not, at its constitutional genesis, made to project strategic power in the world, and while Canada lacks a deep jurisprudential culture of strategic affairs, the federal state indeed has significant strategic capacity; that is, Canada's Constitution suggests considerable Canadian strategic power, even if policy-political praxis does not necessarily translate this theoretical constitutional capacity into on-the-ground outcomes.
\end{abstract}

Key words: Canadian Constitution, Strategy, Power, Foreign Affairs

JEL classification: K10, K30 


\section{Author Contact:}

Irvin Studin

Osgoode Hall Law School, York University

4700 Keele St, Toronto Ontario, M3J 1P3

Email: istudin@hotmail.com 


\title{
CONSTITUTION AND STRATEgY: UNDERSTANDING CANADIAN POWER IN THE WORLD
}

\author{
Irvin Studin ${ }^{*}$
}

"[L]aw and strategy are not merely made in history... They are made of history.” (Philip Bobbitt, The Shield of Achilles, 2002) ${ }^{1}$

In Canada, after the English and the French, perhaps the most significant historical solitudes are the Constitution and strategy. Indeed, while Canada's constitutional framework and its various constitutional debates give ample expression to the first two solitudes, they are largely silent on strategy - strategy here understood in the classical international relations sense of 'strategic' instruments of state employed to project 'strategic' power in the world. ${ }^{2}$

\footnotetext{
* Irvin Studin is assistant director of the Nathanson Centre on Transnational Human Rights, Crime and Security at Osgoode Hall Law School. He lectures at both Osgoode Hall and the Glendon School of Public Affairs (York Univerity), and is founding editorin-chief of Geokrat Magazine. He wishes to sincerely thank Warren Newman, Patrick Monahan, Fred Lazar and Gus Van Harten for commenting on successive drafts of this article.
}

1 Philip Bobbitt, The Shield of Achilles: War, Peace and the Course of History (New York: Anchor Books, 2002), p. 5

${ }^{2}$ It is noteworthy that many definitions of 'strategy' privilege the military aspect of power, as in Colin S. Gray's Modern Strategy (New York: OUP, 1999) at p. 17: "Strategy is the bridge that relates military power to political purpose"; see also Hervé Coutau-Bégarie’s Traité de Stratégie (Paris: Economica, 2002) at p. 27 or Book II, Chapter 1 of Clausewitz's classic Vom Kriege. The U.S. Department of Defense, for its part, defines 'national strategy' more expansively as the "art and science of developing and using the political, economic and psychological powers of a nation-state, together with its armed forces during peace and war, to serve national objectives." [Joint Chiefs of Staff, D.O.D. Dictionary of Military and Associated Terms, JCS Joint Pub 1-02 (Washington, D.C.: GPO, 23 March, 1994) at p. 255] And economic power is emphasized in the important volume from the Russian Academy of Sciences-Economic Institute, called Strategicheskiy Otvet Rossiyi na Vysovy Novovo Veka (Russia's Strategic Response to the Challenges of the New Century) (Moscow: Examen, 2004) . In this 
This constitutional silence is hardly accidental. The seldom examined second recital of the preamble to the Constitution Act, 1867 (once the British North America Act, 1867, and hereafter the '1867 Act'), reads that the "Union would conduce to the Welfare of the Provinces and promote the Interests of the British Empire.” The only provision of the 1867 Act that explicitly references foreign affairs is section 132, although it speaks to the implementation by Canada of imperial or British Empire treaty obligations. But let us return to section 132 later on in this piece. For now, one can propose with reasonable certainty that both the character and paucity of explicit language on strategy in the text of the founding legal document of the modern Canadian state betray a fundamental reality: that Canada, constitutionally speaking, was never intended or expected to be a power player of any note in the world, but rather an appendage or 'auxiliary kingdom' of the British empire-its instruments and interests subsumed to the strategic designs and direction of Westminster. $^{3}$

Canada's astrategic constitutional conception finds expression in both Canadian constitutional scholarship and constitutional jurisprudence. Canadian constitutional scholars and courts have been animated historically by concerns of federalism or federal-provincial division of powers-largely exclusive of foreign or strategic affairs-and, increasingly, particularly since the advent of the Charter of Rights and Freedoms in 1982, questions of civil liberties. (Much like the text of the Constitution Act, 1867, the text of the Constitution Act, 1982-herafter the '1982 Act' - in which the Charter figures prominently, is conspicuously silent on foreign affairs; the domestic realm is king.) International relations scholars or strategic analysts in Canada, in turn, are little

piece, let us be clear, however, that we understand strategy as encompassing both the military and diplomatic instruments that serve Canadian (national) strategic interests or objectives, however defined.

${ }^{3}$ Writes Jack Granatstein in Canada's Army: Waging War and Keeping the Peace (Toronto: University of Toronto Press, 2002) at p. 10: "Strategy was the province of the imperial masters, not the Canadians, whether French- or English-speaking. [...] Strategy was not for Canadians to decide; tactics, perhaps, but strategy, never.” Surely, I would offer, this must mean that our Constitution is at most tactical in character! 
concerned with the Constitution. They focus primarily on the international order (or international structures, systems and dynamics), and typically see the Canadian domestic order-politics, really, far more than the Constitution - as relevant only at the level of strategic decision-making or praxis by the federal government: to go or not to go to war; or more or less funding for defence or foreign affairs. Indeed, certain species of 'realist' international relations scholars, borrowing heavily from the neoclassical economic theory of the firm, may even fancy the domestic order altogether irrelevant.

So we come closer to our problématique: the constitutionalists are radically inward-looking, and the strategists are, with few exceptions, constitutional philistines. The incommensurability would be acceptable were it not for the exotic possibility-nay, probability-that, conceptually speaking, the Constitution and strategy are but flip sides of the same Canadian enterprise (the state), or at least the legitimacy of that enterprise. More precisely, the suggestion is that the Constitution, concerned as it is with law, is representative of the internal legitimacy of the Canadian state, while strategy, concerned as it is with power, is representative of the external legitimacy of the Canadian state. The British historian Michael Howard says as much in his Preface to Philip Bobbitt's Shield of Achilles. He writes:

This is Bobbitt's starting point: "Law and strategy are mutually affecting." There is a constant interaction between the two. Legitimacy itself "is a constitutional idea that is sensitive to strategic events" - not least to a "strategic event" so cataclysmic as losing a war. Nevertheless, although wars may create and mould states, it is the State that creates legitimacy both domestic and external, and it is legitimacy that maintains "peace." If states can no longer maintain their legitimacy, or if their capacity to do so is called into question, then there will be another war, the outcome of which will create a new legitimacy. ${ }^{4}$

\footnotetext{
${ }^{4}$ Michael Howard, in his Preface to Philip Bobbitt's The Shield of Achilles, supra note 1, p. xvi. Bobbitt himself writes in his Prologue, at pp. xxv-xxvi: "The modern state came into existence when it proved necessary to organize a constitutional order that could wage
} 
Henry Kissinger, for all intents and purposes, alludes to this same dyad of constitution and strategy when he defines the state as "by definition the expression of some concept of justice that legitimizes its internal arrangements and of a projection of power that determines its ability to fulfill its minimum functions - that is, to protect its population from foreign dangers and domestic upheaval."5 And yet, if this dyad be truethat is, if there be logical or conceptual interdependence between the two faces of the legitimacy of the Canadian state-, then, as suggested, it finds precious little expression in the psyche of its principal Canadian interpreters.

Since the Statute of Westminster, $1931^{6}$ at the official earliest, although more likely, in practical terms, by the start of the Second World War, when Canada's declaration of war was at last differentiable (if only slightly) from that of the United Kingdom, Canada has effectively acquired the trappings of a proper and serious player in international relations, including an independent diplomacy and an independent capacity to declare (or not to declare) and wage war. It is worth mentioning that while Canada, for reasons stated above, had no formal diplomatic capacity at Confederation, it did have a slight modicum of military power projection against the Americans - to wit, volunteer (nonprofessional) land and naval militias which acted in support of British regulars, for all of which, under section 15 of the 1867 Act, "[t]he Command-in-Chief" was "declared to continue and be vested in the Queen” (in whom "Executive Government and Authority of and over

war more effectively than the feudal or mercantile orders it replaced. [...] The process takes place in the fusing of the inner and outer dominions of authority: law and strategy."

${ }^{5}$ Henry Kissinger, Does America Need a Foreign Policy? Toward a Diplomacy for the $21^{\text {st }}$ Century (New York: Simon \& Schuster, 2001), p. 20.

${ }^{6}$ The Balfour Declaration of 1926, issuing from the imperial conference of 1926, evidently anticipated the Statute of Westminster, which gave the Declaration legislative effect. Jurisprudentially, it was the holding in Croft v. Dunphy, [1933] A.C. 156 that asserted, for the first time, that Canada's federal Parliament, like any sovereign state, could legislate with extraterritorial effect, thereby buttressing section 3 of the Statute of Westminster, 1931, which provided for the same thing. 
Canada" was vested under section 9), and legislative responsibility for which would lie with the federal Parliament under section 91(7), the socalled defence or militia power. However, the Canadian militia, whether mobilized for domestic strategic purposes (such as insurrection or rebellion) or, to the extent possible, deployed internationally-more probably continentally — was, in accordance with the said preamble, to be in the strict service of the interests of the British Empire. (To which the Canadian constitutionalist F.R. Scott adroitly replied: "what does 'promote the interests of the British Empire' mean in law?", ) But when independent diplomatic and military capabilities - strategic capabilitieseventually did accrue to the Canadian state in practice, one could nary deny that Canada was a state that, to some extent or other, could at last project, or attempt to project, independent power - strategic power-in the world. And, in legal-constitutional terms, borrowing from the logic of Scott's query, that this strategic power was no longer in the service of British interests was less interesting a point than the notion that it was the very existence of such independent strategic capabilities (means) that now allowed the Canadian state to pursue strategic interests (ends) of various descriptions and intensities-depending, inter alia, on the preferences and chutzpah of the government of the day, as well as the strategic events in question.

Of course, this leaves us with the remarkable paradox of Canada being able to project strategic power in the world despite the prima facie absence of any explicit (or, more precisely, self-consciously explicit) textual reference to any particular strategic capabilities in either the Constitution Act, 1867 or the Constitution Act, 1982, or in any other Canadian constitutional text, for that matter. ${ }^{8}$ Canada's Constitution, unlike that of,

7 F.R. Scott, "Expanding Concepts of Human Rights", Essays on the Constitution (Toronto: University of Toronto Press, 1977), p. 358.

8 The Statute of Westminister, 1931, is part of Canada's constitutional framework, the definition of which we discuss below. Its section 3 provides that the Canadian Parliament may legislate with extraterritorial effect. This extraterritorial legislative capacity cannot, however, be properly identified with a foreign affairs legislative power per se, as it refers to all federal legislative heads of power, and these are evidently quite different, in functional terms, from foreign affairs properly understood. The Letters Patent Constituting the Office of the Governor-General of Canada, 1947, a prerogative instrument of the Queen and also a arguably a part of the Constitution, on our definition, 
say, Australia ${ }^{9}$, a reasonably comparable former British colony, has no explicit foreign affairs power. And as for the said militia power of section 91(7), perhaps because it was not intended to be understood outside the context of British imperial power, it was, according to the great Canadian jurist Bora Laskin, scarcely developed and "never authoritatively defined" ${ }^{\text {in }}$ in the constitutional jurisprudence.

At first glance, one could therefore be easily forgiven for presuming that Canada's Constitution - the essentially parochial 'iron cage' that frames its internal arrangements-has not much at all to say about Canadian strategic power, notwithstanding the said presumptive conceptual interaction between the state's internal and external authorities; or, in other words, that modern Canadian strategic affairs effectively exist outside the conceptual (although certainly not the legal) orbit of the Constitution. Indeed, many constitutionalists and international strategists seem to have concluded thus-implicitly, if not explicitly-, thereby concretizing our two aforementioned solitudes. The conclusion, however, can be shown to be quite premature. For deep in the bowels, so to speak, of the Constitution, by dint either of genius or serendipity, lie many of the essential building blocks of Canadian strategic power. And the argument being made in this paper is that these building blocks can, first and foremost, be identified, and second, that, notwithstanding the Constitution's astrategic original design, and notwithstanding the ostensibly astrategic interpretation of that Constitution by judges and scholars alike, the Canadian state has emerged with a very solid, indeed powerful, strategic core-one that, in theory, is for the most part constitutionally capable of projecting very substantial strategic power in the world. Praxis, as mentioned, is a quite different matter-and this for a

even if not, strictly speaking, according to the definition provided in section 52(1) of the Constitution Act, 1982, consecrates at section 14 the right of the Governor-General of Canada to accept foreign diplomats on behalf of Canada. This evidently speaks directly, at least in part, to the federal government and foreign affairs - if only for the executive, not the legislative, branch.

${ }^{9}$ Section 51(xxix) of the Commonwealth of Australia Constitution Act, 1900, states that the Commonwealth (federal) government has legislative responsibility for foreign affairs.

${ }^{10}$ Bora Laskin, Canadian Constitutional Law, $4^{\text {th }}$ ed. (Toronto: Carswell, 1975), p. 199. 
variety of historical-political-cultural reasons. For purposes of this paper, therefore, we will concern ourselves with illustrating the parameters of this theoretical constitutional capability. In other words, the task at hand is to explain Canadian strategic power in constitutional terms.

\section{What is Canadian Strategic Power?}

Let us first quickly define a state's power-external power-, in the basic sense, as its capacity to intentionally make or compel a foreign party (usually another state or group of states, and affiliates) do (or not do) something which that party would otherwise not have done (or would have done). It should be stressed, as already suggested, that we are here interested in power as capacity, not power as exercise-except insofar as the exercise helps us to define the capacity. (Exercise, to be clear, is a decision for government, whereas capacity can, on our argument, be explained in constitutional terms.) For purposes of the Constitution, this definition of state power is to be distinguished from any notion of 'soft,' so-called Nyean power that may be projected or, in the legal parlance, 'transplanted' by a state like Canada indirectly or inadvertently (but not through any strategic design) in virtue of, or through, its constitutional regime-for instance, the Charter-, something which may be said to be tantamount to a 'signalling' or 'demonstration' effect on the behaviour other states. It is also to be distinguished from the negative power (or 'drag' or 'rigidity') associated with the numerous processes of constitutional building, bargaining and negotiation that have so marked Canadian history - in particular over the last half century, but indeed over most of the life of the Canadian federation. And given the above, we will offer that strategic power consists in power that is used by the state in the pursuit of strategic interests - such as security, sovereignty, territorial integrity, wealth or prestige-or, more readily, power that is pursued by means of strategic instruments, the most classical and important of which are the state's diplomatic and military instruments. And so, constitutionally speaking, let us propose that the character of Canada's acquired strategic power can at least partially, but nonetheless persuasively, be explained not by the strategic interests (ends) pursued by the state (which, again, have been and continue to be many and variable), 
but by the key strategic instruments, the means-in particular, diplomacy and the military — used over time by the state in aid of such interests.

Naturally, as we are here preoccupied by the nexus between strategic power and the Constitution, it behooves us to emphasize that the type of strategic power of which we speak is evidently that which is exercised through constitutionally legitimate channels-that is, channels permitted by the Constitution. (States can, and evidently often do, exercise strategic power through constitutionally illegitimate channels.) It stands to probable reason, also, that, other things being equal, and leaving aside the numerous and broadly understood possible benefits of federalism for purposes of domestic administration in a country as vast and complex as Canada, and also leaving aside the obvious need for a robust rights framework that can control the arbitrary employ of government power, we will assume that, as a general rule, the more powerful the federal executive (the 'strategic centre,' if you will) in respect of the factors (or elements) of strategic power discussed in the next section, the greater the strategic potency of Canada's diplomatic and military instruments, and therefore the greater the aggregate strategic power of the Canadian state. Moreover, because of the effective fusion of the executive and legislative branches in modern Westminster systems of (majority) government—party discipline oblige-, let us assume that the more expansive the legislative powers of the federal Parliament in respect of a particular factor of strategic power, the greater, in most cases, the power of the federal executive in respect of that same factor of strategic power. ${ }^{11}$

${ }^{11}$ Strictly speaking, in Canadian constitutional law, executive power follows the grant of legislative power, as affirmed in cases like Liquidators of the Maritime Bank v. Receiver General of New Brunswick, [1892] A.C. 437, as well as Mowat v. Casgrain (1897), 6 Que. Q.B. 12. We should also concede, naturally, as this is being written during a period of minority federal government in Canada, that the effective identification of federal legislative powers with executive powers is often weakened, although certainly not emasculated (electoral mandate and control of the machinery of government by the executive oblige) in the context of minority government. Moreover, we should note that the association of strategic power with federal constitutional powers in certain key areas (factors of strategic power) certainly does not preclude the possibility of federalprovincial cooperation in these areas or in the promotion of Canadian strategic interests. (Such intergovernmental cooperation, in constitutional terms, can be understood in virtue of the principle that legislative powers are exhaustively distributed between the federal and provincial governments.) Nor, of course, does it preclude the possibility of federalprovincial competition or conflict in certain areas. To be clear, however, with a few 


\section{THE CONSTITUTIONAL ELEMENTS OF CANADIAN Strategic Power}

Let us also be clear about what is meant by the term Constitution. For the Constitution of Canada, properly understood, is far more-and more complex - than just the Constitution Acts of 1867 and 1982, even though these Acts are clearly the keystones of the 'written' or textual Constitution, as defined in section 52(2) of the 1982 Act. $^{12}$ Indeed, a more labyrinthine body of principles, conventions and, critically, judicial decisions (jurisprudence) comprises the putatively 'unwritten' parts of the Constitution — some of them more 'constitutional' than others. Writes the constitutional scholar Patrick Monahan:

There are [...] many enactments or rules of a constitutional nature that are not included in the definition of the Constitution of Canada in section 52(2) These "unentrenched" documents include all the preConfederation constitutional documents such as the Royal Proclamation of 1763, the Constitutional Act, 1791, and the Union Act, 1840 [...]. Constitutional conventions, ordinary statutes of an organic character, and treaties with Aboriginal peoples are likewise not referred to in section 52 [...]. Since these enactments or rules are not [strictly speaking] part of the Constitution of Canada, they are not

exceptions (see the section below on national economic might), such cooperation or conflict, in our framework, typically falls in the realm of praxis (that is, policy-political choices by each level of government), rather than that of strict constitutional capacity for the federal and provincial governments.

${ }^{12}$ The definition of the Constitution in 52(2) was ruled non-exhaustive in New Brunswick Broadcasting Co. v. Nova Scotia (Speaker of the House of Assembly), [1993] 1 S.C.R. 319. 
subject to the procedures for amendment established by Part V [of the Constitution Act, 1982]. ${ }^{13}$

The Statute of Wesminister, 1931, which, as discussed above, speaks to the legislative equality of the Canadian Parliament with that of Westminster, as well as the capacity of the former to legislate extraterritorially, is doubtless a part of the formal Constitution [Item 17 of the Schedule to the Constitution Act, 1982, referenced in section 52(2)(b)]. The Letters Patent Constituting the Office of the Governor-General of Canada, 1947, however, which empower the Governor-General of Canada, inter alia, to approve the credentials of foreign diplomats, are not, strictly speaking, considered part of the Constitution, according to the list of instruments scheduled to the 1982 Act. Still, on a broader conception of the Constitution, we might well regard these letters patent as an integral part of Canada's constitutional framework, given their genetic connection to the office of the representative of the head of the Canadian state.

The 1867 Act is by a considerable margin the most signal part of the Constitution for purposes of assessing Canadian strategic power. ${ }^{14}$

${ }^{13}$ Patrick Monahan, Constitutional Law, 3d ed. (Toronto: Irwin Law Inc., 2006), p. 178. See the somewhat more pedantic definition of the Constitution given by Gil Rémillard in Le Fédéralisme canadien - Tome I: La Loi constitutionnelle de 1867 (Montréal: Québec/Amérique, 1983) at p. 143: « La constitution matérielle canadienne, c'est-à-dire l'ensemble des règles qui prévoient l'organisation et le fonctionnement de l'État canadien, est formée des éléments suivants: 1. La loi constitutionnelle de 1867 (A.A.N.B.); 2. les amendements qui y ont été apportés; 3. des lois britanniques et canadiennes d'importance constitutionnelle [y compris la Loi constitutionnelle de 1982]; 4. l'interprétation judiciaire; 5. les conventions et coutumes ; 6. la common law et les grands textes constitutionnels britanniques." Quaere whether Monahan, unlike Rémillard, goes too far in including the entire catalogue of pre-Confederation imperial ('constitutional') statutes.

14 We know that John A. Macdonald, the key figure in authoring the British North America Act, 1867 (in particular the Quebec Resolutions of 1864), wanted a strong central government-meaning a preponderance of aggregate federal power in section 91 over aggregate provincial power in section 92. We also know, however, that he cared little for military affairs and never fancied Canada professionalizing the military, let alone being able to independently project strategic power beyond its borders. Quaere: Did this strong central (parochial) state contain the seeds of the eventual strategically sound state described in this article? 
Despite its provincial (or rather 'colonial') design, if one be creative, key elements or building blocks of strategic power may be identified. Specific sections-let us call these strategic sections - of the Act effectively deal with factors or determinants of power that may have material influence on the potency of the two said central strategic instruments of the Canadian state-diplomacy and the military-, and therefore on the aggregate strategic power of the state. These sections implicitly or explicitly address diplomatic and military capabilities per se, but also such factors of strategic power as the pure potency of the executive branch of government, natural resource wealth, national economic might or industrial capacity, as well as population (quality, quantity and distribution). Granted, these categories are very stylized-even crudeand are certainly not mutually exclusive or, for that matter, exhaustive: other factors, such as geography (Canada, after all has the world's second largest land mass) ${ }^{15}$, national morale or character, come to mind, but they are far too abstract and indeed too diffusely treated in the Constitution, and, as a consequence, less susceptible to serious examination. Technology, broadly conceived, would also appear to be strategically material for a modern state like Canada; it, however, is arguably subsumed

\footnotetext{
${ }^{15}$ One of the more exotic and indeed fascinating categories of constitutional-strategic (or 'quasi-constitutional'-strategic) dynamics in Canada relating to the geographic factor of power is the Aboriginal question, as it, in many cases, turns on issues relating quite bluntly to land-for instance, Aboriginal title claims (the legal right to occupy and possess identified land) and Crown (federal or provincial) fiduciary obligations to consult and accommodate Aboriginal rights (of which title is but a subset) relating to disputed lands which the Crown intends to use. For the latter question (i.e. consultation and accommodation), see Haida Nation v. British Columbia, [2004] 3 S.C.R. 511, as well as Taku River Tlingit First Nation v. British Columbia, [2004] 3 S.C.R. 550-two major cases that expound section 35 of the 1982 Act. [Section 35(1) of the 1982 Act recognizes and affirms the existing Aboriginal and treaty rights of Canada's Aboriginal peoples.] On Aboriginal title, see, inter alia, famously, R. v. Van der Peet, [1996] 2 S.C.R. and Delgamuukw v. British Columbia, [1997] 3 S.C.R. 1010. [Of course, many of these Aboriginal dynamics are in fact anticipated by the Royal Proclamation of 1763, which solidifies the argument for its inclusion in a broader conception of the Constitution; see supra note 13.] A proper assessment of the geographic factor of power would have to wrestle not only with these cases, but with a wealth of highly complex and nationally differentiated Aboriginal arrangements-constitutional and quasi-constitutional-that variously affect the aggregate potency of this factor of power. [The Supreme Court has not to date ruled definitively that section 35(1) of the 1982 Act incorporates an inherent right to self-government.]
} 
in the natural resources and economy factors of power. And so the contention here is that, in the apparent absence of deliberate strategic architecture in the Canadian Constitution, the identified elements of power may be usefully 'mined,' so to speak, in order to obtain a more meaningful picture of the strategic power latent in Canada's constitutional makeup.

We have already mentioned two sections of the 1867 Act in which the military instrument finds explicit textual expression-to wit, sections 15 and 91(7). To these we might add the lesser known section 117 (an executive power), which reads that the provinces retain that public property which is not disposed of in the 1867 Act, subject to the right of Canada to "assume any Lands or Public Property required for Fortifications or for the Defence of the Country." There is also, if one be pedantic, the schedule to section 108 (the third schedule to the 1867 Act), which enumerates as federal property at Confederation such strategic assets as military roads, ordnance property and armouries, drill sheds, military clothing and munitions of war. For its part, the diplomatic instrument, as already established, finds no support in an explicit foreign affairs legislative power. However, it is indirectly addressed in the jurisprudence on section 132, the imperial treaty power-most notoriously in the still contested Labour Conventions ${ }^{16}$ decision of 1937, which we soon discuss below. And section 9, which, as mentioned, vests in the Queen executive authority of and over Canada, applies more broadly_-via the royal prerogative - to both the diplomatic and military instruments, as well as to many other manifestations of executive strategic power.

The royal or Crown prerogative, which, for all intents and purposes, provides the constitutional underpinning for the conduct of foreign affairs by the Canadian federal executive, is critical to our understanding of the constitutional treatment of the diplomatic and military instruments. This prerogative, which exists at common law, is said to be a vestige of the arbitrary or discretionary power of the Sovereign. It implicitly finds its place in Canadian constitutionalism by virtue of the influential first recital of the preamble to the 1867 Act, which reads that the Dominion is "under the Crown" and that the Constitution is "similar in Principle to that of the United Kingdom," as well as in the said sections 9 and 15 of the same

${ }^{16}$ A.G. Can v. A.G. Ont. et al., [1937] 1 D.L.R. 673. 
Act. ${ }^{17}$ And in the United Kingdom, it was the sui generis character of international relations - a wholly functional logic - that commended the domain to the exercise of the royal prerogative. On this, the legendary British jurist William Blackstone wrote:

The Crown, therefore, enjoys the sole rights of appointing ambassadors, diplomatic agents, consuls and other officers, through whom intercourse with foreign nations is conducted, and of receiving those of foreign States, of making treaties, declaring peace and war, and generally of conducting all foreign relations. Such matters are entrusted in general to the absolute discretion of the Sovereign, acting through the recognized constitutional channels [...], unfettered by any direct supervision, parliamentary or otherwise. $^{18}$

The Charter-as mentioned, the central piece of the 1982 Act-also has a small handful of (scarcely obvious) strategic sections, even if it be a self-consciously domestic document; that is, a document that was not, for all intents and purposes, meant to have strategic consequence. Section $4(2)$, for instance, speaks to the extension of the life of Parliament (and a

${ }^{17}$ The Supreme Court persuasively tied sections 9 and 15 of the 1867 Act to the royal prerogative in In Re Resolution to Amend the Constitution, [1981] 1 S.C.R. 753. In its majority holding, the Court stated: 'A substantial part of the rules of the Canadian constitution are written. They are contained not in a single document called a constitution but in a great variety of statutes some of which have been enacted by the Parliament at Westminster. [...] Another part of the Constitution of Canada consists of the rules of the common law. These are rules which the courts have developed over the centuries in the discharge of their judicial duties. An important portion of these rules concerns the prerogative of the Crown. Sections 9 and 15 of the B.N.A. Act provide [...]. But the Act does not otherwise say very much with respect to the elements of "Executive Government and Authority" and one must look at the common law to find out what they are, apart from authority delegated by the executive by statute.'

${ }^{18}$ Book 1, Chapter 7 of Sir William Blackstone's Commentaries on the Laws of England (Oxford: Clarendon Press, 1765-69): http://www.lonang.com/exlibris/blackstone/bla107.htm 
legislative assembly) "[i]n time of real or apprehended war, invasion or insurrection." The mobility rights in section 6 may be seen, inter alia, as a proxy for assessing the power (or, more likely, lack of power) of the state in determining population placement or distribution. There is the section 7 "right to life, liberty and security of the person," which has been invoked in several important Canadian cases, discussed below, involving strategy, as well as the notwithstanding clause in section 33. And, of course, under section 1, all of these rights are guaranteed by the Charter "subject only to such limits prescribed by law as can be demonstrably justified in a free and democratic society."

A good number of strategic sections in both the 1867 and 1982 Acts have not yet been treated, but it is sufficient to say at this juncture that for all of the strategic sections of the Constitution (indeed, as with virtually all sections of the Constitution), a mere textual reading fails to convey the actual meaning or import of the provision in question. For this, given the scope of Canada's unwritten Constitution, as Bora Laskin tried to do with the militia power, one must inevitably look to the jurisprudence on each strategic section (the 'unwritten' Constitution, as it were) to see how judges have defined or interpreted each section in key cases. One ought also to survey, in concert with these strategic sections, relevant associated doctrines, principles, conventions and indeed, in some cases, without making the Canadian Constitution overinclusive, certain major statutes that may effectively be said to have 'quasi-constitutional' status, given their potential impact on political praxis and the likelihood that they are little susceptible to material amendment or repeal in the foreseeable future.

The following table (Table 1) provides a stylized breakdown of the sections of the Constitution most associated with key factors or elements of Canadian strategic power. Taken together, these strategic sections may be said to make up what we will call Canada's Strategic Constitution. Diplomacy and the military - for all practical intents and purposes-may be thought of as both elements of Canadian power and the pivotal instruments or servants of this power. It is presumed that each of the other elements of power, taken on its own or in combination with one or more other elements, has material influence-positive or negative-on the 
potency of the diplomatic and military instruments. ${ }^{19}$ The challenge before us, then, is to determine whether jurisprudence on each of these sections, combined with analysis of relevant doctrines, conventions and statutes can add 'meat to the [textual] bones' of each of these elements of power (the bones of the 'Strategic Constitution,' as it were) in order to give us a more meaningful constitutional picture of Canada's strategic power. The distilled picture may in the end prove as close to an 'algorithm' as possible in the nuanced interplay between the Constitution and strategy in Canada.

\footnotetext{
${ }^{19}$ If one be pedantic, it is more precise to offer that the relative influence of each factor or element of strategic power on the state's aggregate strategic power is, in constitutional terms, a function both of the potential raw magnitude or scope of the factor or element and, just as importantly, the extent to which all or part of that factor or element can be mobilized to inform one or both of the state's diplomatic and military instruments. It should also be noted that we are here interested in the case law for each of the strategic sections of the Constitution, and not, strictly speaking, case law relating to the specific categories or factors or elements (per se) of power, mindful as we are of the warning of Justice Beetz in the Anti-Inflation Reference, infra note 53, that excessively diffuse subject matters should not be seen as a legitimate basis for exclusive legislative power for either the federal or provincial government.
} 
Table 1: Canada's Strategic Constitution

\begin{tabular}{|c|c|c|}
\hline \begin{tabular}{l} 
Power Element \} $\\
{\text { Document }}$ & Constitution Act, 1867 & $\begin{array}{l}\text { Charter of Rights and } \\
\text { Freedoms (in Constitution } \\
\text { Act, 1982)* }\end{array}$ \\
\hline Diplomacy & $\begin{array}{l}\text { Preamble/royal } \\
\text { prerogative; ss. 9; s. } \\
91 \text { general power } \\
\text { (POGG); } 132\end{array}$ & \multirow{6}{*}{ ss. $1 ; 4(2) ; 6 ; 7-14 ; 33$} \\
\hline Military & $\begin{array}{l}\text { Preamble/royal } \\
\text { prerogative; ss. 9, 15; } \\
91(7) ; 108 ; 117\end{array}$ & \\
\hline $\begin{array}{l}\text { Executive Strength of } \\
\text { Central (Federal) } \\
\text { Government }\end{array}$ & $\begin{array}{l}\text { Preamble/royal } \\
\text { prerogative; ss. 9; } \\
\text { POGG; 91(11); 91(29); } \\
\text { 92(10)(c); 91(27) }\end{array}$ & \\
\hline $\begin{array}{l}\text { Natural Resources (and } \\
\text { Food) }\end{array}$ & $\begin{array}{l}\text { SS. 91(1A); 92A; 95; } \\
\text { 108; } 109\end{array}$ & \\
\hline Economy & $\begin{array}{l}\text { POGG; ss. 91(1A); } \\
\text { 91(2); 91(3); 92(10); } \\
\text { 92(13); 92(16) }\end{array}$ & \\
\hline Population & ss. 91(25); 95 & \\
\hline
\end{tabular}
\end{tabular}

*The Charter provisions that make up Canada's Strategic Constitution are those that are most likely to come into play against (or indeed, suffuse) exercises of government power based on the common law or legislative heads of powers cited in the 1867 and 1982 Acts. In this sense, they cannot easily be separated into discrete categories along the lines of the various elements or factors of power listed in the second column.

\section{FEDERALISM}

Without a doubt, a defining characteristic of the Canadian Constitution is its federal character. Sovereignty-executive and legislative power-is divided exhaustively between the federal and provincial governments. And notwithstanding the absence of a formal federal foreign affairs power or genuine strategic intent, the Constitution Act, 1867, textually speaking, paints the picture of a reasonably centralized federation. On paper, the federal government may still disallow provincial legislation or, via a provincial lieutenant-governor, reserve provincial legislation for approval by the federal government, even if by constitutional convention these capacities are widely thought to be 
obsolete. More relevant, however, is the reality that most of the levers of strategic power-the militia, along with significant macroeconomic, criminal law, emergency and nationalization powers-are prima facie housed with the federal Parliament and government. Legislative responsibility for immigration, a key lever for increasing the quantity and quality of the national population, which in turn provides fuel for the state's military, diplomatic corps and industrial base, is divided between Parliament and the provincial legislatures, subject to federal paramountcy; that is, provincial immigration legislation is operative only insofar as it is non-repugnant to federal legislation. Parliament also has concurrent but overriding legislative authority over agriculture, which is indissociably linked with food supply. (We very briefly discuss agriculture and food supply in our section on natural resources.) Having said this, legislative responsibility for more traditional natural resources-minerals, metals, forestry and energy goods-, rather astrategically, lies with the provinces, a fact concretized by the 1982 insertion into the 1867 Act of section 92A. (We might also note, parenthetically, that legislative responsibility for education, among many other variables, is with the provinces. And while we have not identified education as a strict strategic factor or element of power, a none too ambitious case could likely be made that the trainingintellectual, cultural and other —of the national population may impact the quality of the diplomatic and military instruments of the state, and that, conversely, the absence of such a lever for Parliament may mean that, quite astrategically, the federal state has little direct control over the 'talent' that eventually populates and runs Canadian diplomacy and the Canadian Forces.)

Jurisprudence in each of the above strategic areas has in many cases drastically altered the prima facie design of the fathers of Confederation. The federation has become far more decentralized than planned. We discuss the jurisprudence, over the course of this article, for each of the strategic sections outlined in Table 1. For now, however, it is enough to note that prior to the advent of the Charter (a largely afederal document), the 'world-view' of Canadian jurisprudence-even in respect of matters strategic - was conditioned almost unexceptionally by concerns of domestic federalism. It follows that commentators like H. Scott Fairley have suggested that "[i]n the absence of textual guidance, notions of divided autonomy gleaned from the jurisprudence of Canadian federalism, not the implications of national sovereignty [or national strategic power, 
for that matter], came to dominate the judicial interpretation of constitutional principle in relation to the subject of external affairs."20

The point is that, because of the astrategic conception of the Constitution, and because, the Charter aside, the courts (the Judicial Committee of the Privy Council chief among them) have by and large tended to see the "judicial process of applying the federal principle to a symmetrical distribution of legislative and executive powers [as providing] a complete and powerful account of the Canadian federal state," 21 the serious business of strategy has nary been explored in their interpretation of the Constitution; at least not in a conscientious sense. This is as much a problem of constitutional design as it is of jurisprudential culture, but the implication is just the same: the Constitution has to date not been interpreted by judges in a way that is properly sensitive to the legitimate strategic role that the Canadian state today plays and indeed may play (again, if it so wishes) in practice. That is, the general inward-lookingness of Canadian jurisprudence-obsessed as it has been with questions of division of powers and, since 1982, Charter rights - has understandably failed to give proper weight to the factual emergence, in policy-political terms, of a Canadian international strategic personality. And still, we argue here that notwithstanding this lack of strategic culture in the judicature (and among jurists), the constitutional structure or framework that has emerged over the years is in many, although not all, critical respects strategically solid, and the Canadian state as a result strategically powerful-in constitutional terms. (We stress here once more that this power to which we refer is capacity, rather than exercise.)

Finally, it behooves us to note the exceptional case of Quebec. In strategic terms, Quebec has been by some margin the greatest

${ }^{20}$ H. Scott Fairley, Canada, External Affairs and the Constitution: A Theory of Judicial Review (S.J.D. Dissertation, Harvard Law School, 1987) [unpublished], p. 6. See also R.C.B. Risk, "Constitutional Scholarship in the Nineteenth Century: Making Federalism Work” (1996) U.T.L.J. 427-457. Risk notes at p. 432 that nineteenth century English Canadian legal scholars shared one basic belief: that "the essence of the Canadian constitution was the British constitution coupled with federalism [...].”

${ }^{21}$ Ibid., p. 46. 
complicating factor in Canadian federalism and, by extension, for Canadian strategic power. Like several other provinces, Quebec has an ambitious programme of so-called 'constituent (provincial) diplomacy,' in which it engages with other nation-states and sub-national units in its areas of constitutional responsibility. Indeed, since the Quiet Revolution of the 1960s, all Quebec governments have, for all intents and purposes, been guided by the Gérin-Lajoie doctrine, which holds that, in its areas of constitutional jurisdiction (sections 92, 92A, 93 and 95 of the 1867 Act), Quebec's powers are not limited to the territorial province. The vast majority of this 'diplomacy' is transactional, falling well below the threshold of what we understand to be strategic. (It stands to reason that partial diplomatic representation for Quebec in international cultural organizations like UNESCO - a state of affairs negotiated under the Martin government and confirmed under the last Harper government-is of far less strategic consequence than potential diplomatic lobbying by that province's government for political recognition among foreign states in the context of future Canadian constitutional crises.) However, Quebec has also in practice been at the core of two conscription crises and was quite possibly material to the 2003 decision of the federal government not to go to war in Iraq, given the historical antipathy of the Québécois to distant military adventure. And yet the province's disproportionate strategic impact on the federal state appears little explained, strictly speaking, by the Constitution-textually or jurisprudentially. Both the Constitution Acts of 1867 and 1982 make asymmetric references to traditional Quebec concerns or, by proxy, French language, cultural and religious or denominational predilections and protections. Moreover, the Quebec Act, 1774, the basic principles of which are arguably part of the above mentioned 'unentrenched' constitution, in section 8 stated that "in all matters relative to property and civil rights, resort shall be had to the [pre-conquest French civil law] for the decision of the same." Such asymmetrical references may well have given Quebec de facto, although not de jure, special status in Canada, but they do not appear, constitutionally speaking, to pertain directly to the elements of the strategic power of the state; that is, they principally refer almost strictly to the internal arrangements of the Canadian state.

In fact, however, Quebec is very much at the heart of the constitutionalstrategic logic of Canadian federalism - in at least two key senses. First, naturally, let us concede that Quebec, then Canada-East, was extremely 
influential in the original division of legislative powers, strategic and otherwise, in sections 91 and 92 of the Constitution Act, 1867. ${ }^{22}$ (The reference to "property and civil rights" in the old Quebec Act led directly to the influential vernacular of "property and civil rights" in section 92(13) of the Constitution Act, 1867, which, as will be explained later, has been the bane of the highly strategic federal trade and commerce power. ${ }^{23}$ ) Second, a number of commentators have suggested (controversially, one should add) that a number of decentralizing Privy Council and even Supreme Court decisions - strategic and otherwise-in the last century were much in keeping with, and may have even been based upon a certain

${ }^{22}$ In his recent book, John A., The Man Who Made Us - Volume 1 (Toronto: Random House, 2007), Richard Gwyn observes that, although the division of powers has been for Canada a perennial topic of political and jurisprudential debate, it was scarcely debated in the very rapid drafting of the Quebec Resolutions at the Quebec Conference in 1864. Having said this, I would argue that many of the section 92 (and 93) heads of provincial power, starting with section 92(13) on property and civil rights, were strongly anticipated by earlier imperial acts in British North America, such as the Quebec Act, 1774. I would also humbly wager that fathers of Confederation like G.E. Cartier and E.P. Taché, both avowed French-Canadian autonomistes, would have made their preferences for certain section 92 powers exceedingly plain to Macdonald as he prepared the consolidated position of the United Province of Canada in the period prefatory to the Quebec Conference.

${ }^{23}$ In the pivotal case of Citizens' Insurance v. Parsons, [1881] 7 A.C. 96, the Judicial Committee of the Privy Council used the logic of section 94 of the 1867 Act relating to uniformity of laws relating to 'property and civil rights' among three of the four original provinces (Quebec excluded) to deduce that the laws in question referred to the equivalent of the body of laws covered exceptionally by the Quebec Civil Code (at the time the Code civil du Bas-Canada, predicated on the coutumes de Paris) for the province of Quebec. As such, the property and civil rights section [section 91(13)] of the 1867 Act became a de facto residuary clause in the jurisprudence for all matter of 'civil law' (non criminal law) questions, including, inter alia, contractual rights, labour relations, securities regulation and agricultural products. For the record, section 94 reads as follows: "Notwithstanding anything in this Act, the Parliament of Canada may make Provision for the Uniformity of all or any of the Laws relative to Property and Civil Rights in Ontario, Nova Scotia, and New Brunswick, and of the Procedure of all or any of the Courts in those Three Provinces, and from and after the passing of any Act in that Behalf the Power of the Parliament of Canada to make Laws in relation to any Matter comprised in any such Act shall, notwithstanding anything in this Act, be unrestricted; but any Act of the Parliament of Canada making Provision for such Uniformity shall not have effect in any Province unless and until it is adopted and enacted as Law by the Legislature thereof.” 
reading of the political winds in Canada; centrifugal winds that often blew strongest and indeed continue to blow strongest from Quebec. Wrote Trudeau in Federalism and the French Canadians: "[i]f the law lords had not leaned in that [provincial] direction, Quebec separation might not be a threat today; it might be an accomplished fact."24

\section{DIPLOMACY}

Diplomacy is one of the two cardinal instruments of Canadian strategic power identified in this paper. The other instrument is the military. Both diplomacy and the military are also, as mentioned, factors or elements of this strategic power. As elements, both evidently influence aggregate national strategic power, as expressed by these same diplomatic and military instruments. (For instance, in simple terms, a strong military influences not only the military, by identity, but may also, as with, say, major economic capacity, greatly enhance diplomacy.) Of diplomacy, the German-American power theorist Hans Morgenthau once wrote:

Of all the factors that make for the power of a nation, the most important, however unstable, is the quality of diplomacy. [...] The conduct of a nation's foreign affairs by its diplomats is for national power in peace what military strategy and tactics by its military leaders are for national power in war. It is the art of bringing the different elements of the national power to bear with maximum effect upon

\footnotetext{
${ }^{24}$ Pierre Elliott Trudeau, Federalism and the French Canadians (Toronto: MacMillan, 1968), p. 198. Of course, this may be a slightly tendentious view-one that neglects the obvious role of Ontario, especially under the rule of Oliver Mowatt, in driving a number of the Privy Council challenges in the late nineteenth and early twentieth centuries. Still, even in consulting today what is arguably one of the two leading constitutional treatises in Quebec, Droit constitutionnel, 4e éd. (Québec: Éditions Yvon Blais, 2002), by Henri Brun and Guy Tremblay, one quickly observes that the decentralist imperative is a clear leitmotiv. Granted, a perhaps equally influential text, the late Gérald-A. Beaudoin's La constitution du Canada: institutions, partage des pouvoirs, Charte canadienne des droits et libertés (Montréal: Wilson \& Lafleur Ltée, 2004), does not have evidence of such a leitmotiv.
} 
those points in the international situation which concern the national interest most directly. ${ }^{25}$

Of course, with the decline of the conventional foreign ministry and the concomitant rise of internationally active 'domestic' ministries (or, in the case of Canada, the effective return to the original model of the prime minister as foreign minister), it is not just diplomats who carry out the business of diplomacy. Rather, diplomacy as we here understand it, is broadly conceived to include such subsidiary strategic instruments as, inter alia, treaties (including trade and investment agreements, although we discuss these in the section on national economic might), development aid, sanctions, intelligence and 'information sharing.' It also includes such strategic capabilities as coercion, negotiation, lobbying, important (strategic) appointments and the international deployment of certain national assets. We will treat only some of these.

One quickly notes that treaties, while once considered the principal and classical currency of state-to-state diplomacy, are today but one of multiple instruments of strategic diplomacy-indeed, arguably a diminishing one in Canadian politics, both in absolute and relative terms. ${ }^{26}$ And yet, paradoxically, because of the proliferation of scholarly commentary on the Labour Conventions case of $1937,,^{27}$ - which, in

${ }^{25}$ Hans J. Morgenthau, Politics Among Nations: The Struggle for Power and Peace (Boston: McGraw-Hill, 1993), p. 155.

${ }^{26}$ L. Wildhaber writes in Treaty-Making Power and Constitution: An International and Comparative Study (Basel: Helbing \& Lichtenhahn, 1971) at p. 1: "A cursory examination of the United States Constitution demonstrates that at the end of the 18th century, the conduct of foreign relations included relatively few matters: war, neutrality, and peace; treaties; foreign commerce; transfer of territory; appointment and reception of diplomats; definition and punishment of crimes against international law (piracy). Today, the scope, density and intensity of foreign relations have significantly increased, decisionmaking techniques have changed, the range of diplomatic instruments has been refined." Indeed, in the United States, since the Second World War, congressional-executive (international) agreements have been used with greater frequency than formal treaties by a significant factor. See infra note 30 .

27 See, inter alia, Torsten H. Strom and Peter Finkle, “Treaty Implementation: The Canadian Game Needs Australian Rules” (1993) 25 Ottawa L. Rev. 39; G.V. La Forest “The Labour Conventions Case Revisited” (1974) 12 Can. Y.B. Int'l L. 137; R. St. J. 
interpreting the imperial treaty implementation provision of section 132 of the 1867 Act, and in conceiving of the division of powers between the federal and provincial governments as "watertight compartments," distributed treaty implementation power between the federal and provincial governments (depending on whether a treaty subject matter falls under federal, provincial or joint jurisdiction) - , the constitutional debate about foreign affairs (or, more broadly, strategy) in Canada is to this day disproportionately preoccupied with the question of treaties. Specifically, the critics of the decision in the Labour Conventions case continue to denounce it as having emasculated not only the federal treaty implementation power, but also, in practice, the federal capacity to negotiate international treaties purposefully and efficiently, a power formally and exclusively reserved for the federal government under the royal prerogative-forced as the federal government often is to pre-consult extensively, and sometimes unsuccessfully, with provinces.

From a strictly strategic perspective, the critique is not misplaced. The state of the Canadian federal treaty power stands in marked contrast, for instance, with that of the Australian Commonwealth (federal) government - as mentioned, a government highly comparable to that of Canada-, for which the Commonwealth of Australia Constitution Act, 1900 provides an explicit external affairs power in section 51(xxix), and for which the Australian High Court decided favourably in two landmark cases involving treaty powers in the early 1980s: Koowarta ${ }^{28}$ and, most importantly, Tasmanian Dam ${ }^{29}$. In both cases, the High Court affirmed

Macdonald, "International Treaty Law and the Domestic Law of Canada” (1975) 2 Dalhousie L.J. 307; R.E. Sullivan, "Jurisdiction to Negotiate and Implement Free Trade Agreements in Canada (1987) 24:2 U.W.O. L. Rev. 63; and the famous piece by F.R. Scott, “Labour Conventions Case: Lord Wright's Undisclosed Dissent?” (1956) 34 Can. Bar Rev. 114. This is a small sample. By comparison, there are terribly few scholarly pieces on the relationship between the Constitution and foreign affairs or the Constitution and defence, including in the canonical Peter Hogg text, [Constitutional Law of Canada, 2007 student ed. (Scarborough: Carswell, 2007), and none at all, it appears, on the broader relationship between the Constitution and strategy.

${ }^{28}$ Koowarta v. Bjelke-Petersen (1982), 153 C.L.R. 168.

${ }^{29}$ Commonwealth v. Tasmania (1983), 158 C.L.R. 1. Note: The U.S. Constitution, for its part, provides for the executive branch (the President) to negotiate international treaties, and for these to be approved by two-thirds of the members of the Senate (part of 
that the Commonwealth government had constitutional authority, under section 51 (xxix), to unilaterally implement international treaties, even those affecting areas of State responsibility. Suffice it to say that the Commonwealth government has since been very activist in strategically (on occasion, some might suggest even colourably) levering the external affairs section and the concomitant expansive treaty power. (By contrast, as a practical example of the strategic emasculation of the Canadian federal executive in the area of treaties, even at the negotiation phase, the Government of Canada has to date had considerable difficulty agreeing on a consolidated 'Canadian' position in respect of a number of major trade deals, including with the European Union, as a result of the need to regularly consult the provinces on jurisdictional matters that would presumably affect the implementability of an eventual agreement.) ${ }^{30}$

the legislative branch). A treaty thus approved by the Senate becomes the law of the land, irrespective of whether the subject matter of the treaty would traditionally fall under federal or state jurisdiction. Power over funding of treaty obligations lies with the legislative branch (all of Congress), not with the executive branch.

${ }^{30}$ Comparisons of Canadian and Australian treaty powers with those of the United States are not obviously instructive, although wholly interesting. Article II, section 2, clause 2 of the U.S. Constitution states that the President "shall have Power, by and with the Advice and Consent of the Senate to make Treaties, provided two thirds of the Senators present concur [...]." As in Australia, federalism concerns in America, as famously affirmed in Missouri v. Holland [252 U.S. 416 (1920)], do not constitute a substantial bar to the subject matter of American treaty-making, given that treaties become "the supreme Law of the Land," according to Article VI, clause 2 of the Constitution, and in spite of the Tenth Amendment, which reserves to the States (and the American people) constitutional powers not otherwise delegated to the federal government. However, the "advice and consent" requirement can often mean that the Senate (part of the legislative branch) may meaningfully influence or condition executive (presidential) negotiation of international treaties. The need to satisfy a Senate supermajority for passage of treaties would also doubtless be assimilated into executive negotiation-and, in this sense, the U.S. federal legislative branch could be thought to play a role somewhat akin to that of Canada's provinces in dulling the potency of the federal diplomatic function. That said, treaties in the U.S. have been in great decline since the Second World War, with the executive branch heavily privileging congressional-executive agreements (or, more rarely, where the executive has plenary power, sole executive agreements) over proper treaties on a wide variety of subject matters; see, for instance, the World Trade Organization (WTO) Agreement and bilateral or trilateral tariff (trade) agreements such as the North American Free Trade Agreement (NAFTA). These congressional-executive agreements require approval by simple majority in both houses of Congress, and originate in statutes authorizing the President to negotiate and enter into given agreements with 
Labour Conventions notwithstanding, Canadian diplomatic activity-as defined in this paper-remains highly concentrated in the federal executive. This is very much on account of, and consistent with, the continued dominance of the royal prerogative in strategic affairs. And while legislation in Canada has gradually clipped or displaced the royal prerogative (which, as we will recall, exists at common law) in matters purely domestic or otherwise astrategic, there has in Canada been a distinctive dearth of legislative override of the prerogative in matters external or (to a lesser extent) strategic. (Where there is proper foreign affairs legislation, it would typically fall under the section 91 general power, as a residual power.) The Department of Foreign Affairs and International Trade Act - to take perhaps the most obvious example-is notoriously laconic (in all, only thirteen sections long) and transactional. Moreover, until the recent passage of a private member's bill (Bill C293)—the Official Development Assistance Accountability Act-, there existed no formal Canadian legislation touching on international development assistance. This new Act defines official development assistance (ODA) in law and provides for specific and regular reporting requirements on Canadian ODA activities by the government to Parliament. Still, the Act leaves much of the royal prerogative of the government untouched, which means that the Canadian International Development Agency (CIDA) remains without formal enabling legislation and that its activities are still largely governed by the prerogativepresumably consistent with the predilection of the government; hence, presumably, its support of the private member's bill.

What of intelligence? We discuss security intelligence below, noting that Canada does not at this time of writing have a pure or classical foreign intelligence agency. Having said this, a new (human) foreign intelligence agency, once softly mooted and later abandoned by the last Harper government, distinct from the Canadian Security Intelligence Service

foreign governments. They are, as a general rule, easier to approve and amend in Congress than treaties-hence their strategic attractiveness to the American executive branch. The constitutionality of the NAFTA - by implication, congressional-executive (trade) agreements-in American law was upheld as a non-justiciable political question in USA Foundation v. United States, 242 F.3d 1300 (11 ${ }^{\text {th }}$ Cir. 2001), with the U.S. Supreme Court subsequently denying review of the case. 
(CSIS) and operating outside the strict ambit of both sections 12 and 16 of the CSIS Act (itself 'quasi-constitutional,' on our loose understanding), could arguably be stood up on the strength of the royal prerogative alone; that is, without enabling legislation. ${ }^{31}$ The Canadian Forces, outside of the (foreign) communications intelligence capability provided by the Canadian Security Establishment (CSE) ${ }^{32}$, which is regulated under the

${ }^{31}$ Section 12 of the CSIS Act restricts CSIS intelligence activities strictly to suspected threats relating to the security of Canada (in other words, to security intelligence). It should be noted, however, that in the important holding in Henrie v. Canada, [1989] 2 F.C. 229, the Federal Court specified that "[t]here are few limits upon the kinds of security information, often obtained on a long-term basis, which may prove useful in identifying a threat.” CSIS generally views section 12 as having no territorial restriction, provided the intelligence sought is of a 'security' nature. (This extraterritorial assumption was questioned in Justice Blanchard's obiter in the recent case Re. Canadian Security Intelligence Service Act, [2007] F.C.J. No. 1780.) Section 16, for its part, geographically restricts CSIS intelligence activities relating to the defence of Canada and Canadian foreign affairs-in essence, the military and diplomatic instruments that concern us here-to territorial Canada. A proper foreign intelligence agency, on the strength of the royal prerogative, could presumably at least allow for intelligence activities relating to defence and diplomacy outside of Canada. A decision by the government to launch the agency, whether publicized or not, would not itself be subject to the Charter, as it would be considered an executive decision of high policy. A more controversial question, however, is whether the foreign activities of the agency's employees or operatives would be subject to the Charter. Until the recent holding in Khadr, discussed below at note 44, one could rely on Hape, discussed below at note 42, and also Re. Canadian Security Intelligence Act, which affirms Hape, to presume that the Charter does not, absent the consent of the host state, apply to Canadian intelligence activities abroad. Khadr now seems to have greatly complicated (indeed, confused) things, apparently implying that involvement by Canadian government agents, even potential foreign intelligence agents, in processes that are illegal at international law, could be considered contrary to at least section 7 of the Charter - to wit, the fundamental justice (procedural) requirement.

${ }^{32}$ In addition to foreign signals intelligence, the CSE is also responsible for the protection of the Government of Canada's electronic information infrastructure, and of information infrastructures of importance to the Government of Canada. Its legislative basis under the National Defence Act was enacted only in 2001 via the Anti-Terrorism Act. Prior to that, the agency operated via the royal prerogative. It is also interesting to note that Canada's geography, although a factor of power largely too abstract to properly capture in constitutional terms, is given concrete strategic expression through the signals intelligence function; that is, Canada's vast geography (and indeed its proximity to major strategic players like Russia and a number of Asian states) is levered by virtue of the constitutional power of the federal government, previously under the prerogative and now under the militia power, to collect signals intelligence in relation to foreign enemies and 
National Defence Act, already enjoy such an in-house, albeit small, foreign (human) and analytic (indeed, 'all-sources') intelligence capability in the form of the Chief of Defence Intelligence (CDI) organization, which operates solely under the aegis of the royal prerogative. Similarly, to take but one more example, the existence and character of diplomatic reporting-quasi-foreign intelligence, as it were-emanating from Canadian embassies and consulates around the world, as well as the growing analytic intelligence capability of the International Assessment Staff (IAS) in the Privy Council Office are also essentially extralegislative, underpinned only by the royal prerogative.

The Canadian courts, for their part, like their counterparts in other Commonwealth countries, even if they have historically been given to judicial review of prerogative powers in matters domestic, until fairly recently took the royal prerogative to be largely non-justiciable in most matters strategic - particularly in relation to foreign affairs, defence and national security. As in other Commonwealth countries, as well as in the United States ${ }^{33}$, this presumption of non-justiciability was a function both of a perception by the judiciary that there was functional propriety in unfettered executive discretion in strategic matters (again, in foreign affairs, defence and national security) and a corresponding reluctance by that same judiciary to make decisions that, institutionally speaking, may be beyond its ken.

threats-even if, in extremis, such intelligence is obtained from in-Canada private conversations in respect of foreign enemies or threats-from intercept stations across the country.

33 In the United States, the non-justiciability of executive decisions enjoys the moniker 'political questions'-itself doubtless derivative of the British royal prerogative. In the matter of political questions and 'strategy' (national security, war and peace, foreign affairs, etc.), there is a live and intense American debate about the nature and scope of the political questions doctrine. The protagonists in this debate include the likes of John Yoo, The Powers of War and Peace: The Constitution and Foreign Affairs After 9/11 (Chicago: University of Chicago Press, 2005), Harold Koh, The National Security Constitution: Sharing Power After the Iran-Contra Affair (New Haven: Yale University Press, 1990), Michael Glennon, Constitutional Diplomacy (Princeton, N.J.: Princeton University Press, 1990) and Thomas Franck, Political Questions/Judicial Answers (Princeton, N.J.: Princeton University Press, 1992). 
This deference began to yield to more aggressive judicial treatment of prerogative powers in the final quarter of the last century. By 1985, the House of Lords, in Council of Civil Service Unions v. Minister for Civil Service $^{34}$, had determined that, in principle, executive action was no longer immune from judicial review merely on account of it being carried out via the royal prerogative, although certain prerogative powers or subjects (in the event, national security powers in relation to the British signals intelligence agency - the Government Communications Headquarters, or GCHQ, effectively equivalent to Canada's CSE) were not in and of themselves justiciable. In the same year, the Supreme Court of Canada, building on this House of Lords decision, levered the Charter to state more ambitiously in Operation Dismantle ${ }^{35}$ that it could not "relinquish justice on the basis that an issue [such as a strategic decision of government] is inherently non-justiciable or raises so-called political questions.” We discuss Operation Dismantle and a related line of cases below in the context of the military, but suffice it to say at this juncture that the decision in that case, both in its own right and given some of the cognate cases that followed it, was, in strategic terms, more bluster than substance. The royal prerogative in relation to defence (declaration of war and military operations) remains largely unmolested by the judiciary, and none of these decisions has meaningfully dented federal prerogative power or indeed decision-making in relation to most of the key components of diplomacy, including the making of treaties (as distinguished from their implementation), development aid, all species of negotiation, strategic policy planning, ambassadorial or ambassador-like appointments, as well as the deployment of strategic national assets, including embassies and envoys. We discuss in the next section on the military the Charter limitation put on the prerogative in the recent Khadr $^{36}$ holding, for which the jurisprudential dust has not yet settled, but which, we must concede, for the first time in Canadian jurisprudence, threatens to non-negligibly clip some of the royal prerogative in relation to strategy.

${ }^{34}$ Council of Civil Service Unions v. Minister for Civil Service, [1985] A.C. 374. Lord Radcliffe stated that the exercise of the prerogative is amenable to judicial review if it affects individual rights. This anticipated the subsequent Canadian holding in Operation Dismantle, infra note 35.

${ }^{35}$ Operation Dismantle Inc. v. R., [1985] 1 S.C.R. 441.

${ }^{36}$ Infra note 44. 
But if the 'strategic' royal prerogative is in Canada as yet largely whole and untrammelled by the courts, then it is legislation and federalism that have arguably controlled or channelled some of the broad scope of the diplomatic prerogative. Labour Conventions oblige, federalism is a pivotal dynamic, for instance, in the implementation of international trade and investment agreements - even if treaty-making, strictly speaking, is still a creature of the prerogative. (As discussed above, negotiation of treaties is also in practice greatly affected by the federalism dynamic; in short, the federal government can only decisively or 'muscularly' negotiate a treaty if it expects to be able to implement it.) As for legislation, in addition to replacing certain prerogative aspects of intelligence, it controls aspects of such strategic diplomatic capabilities as economic sanctions, in particular under the federal Special Economic Measures Act, which provides for the restriction or prohibition by the federal government, independently of the provinces, of a catalogue of activities or transactions between Canada, Canadian citizens and Canadian companies with a foreign state or organization-including the freezing or confiscation of designated foreign property in Canada-for purposes of punishing or otherwise influencing the behaviour of that state or organization. $^{37}$

And still, jurisprudence, federalism and legislation have left wholly unaffected a host of diplomatic capabilities underpinned by the prerogative. These include the prerogative of the federal government to recognize or (threaten) not to recognize foreign states and governments, create, join or leave any number of important international councils, such as the G-7, G-8 or now G-20 (none of which enjoys an enabling treaty), broker international peace and security agreements, join or quit a given military alliance or coalition, and even to recall an ambassador or expel a foreign ambassador, envoy or official. We turn to the question of the military instrument in the next section.

37 Canada's sanctions regime is, strictly speaking, a function of a triad of statutes, including the Special Economic Measures Act, the United Nations Act and the Export and Import Permits Act. The Special Economic Measures Act is the dominant statute for purposes of discretionary sanctions. There has to date been no jurisprudence in relation to it. We discuss the Export and Import Permits Act in the section on natural resources below. 
[VoL. 05 No. 01

\section{THE MiLitARY}

Because the royal prerogative is and remains, constitutionally speaking, so dominant in governing Canada's strategic military affairs, including declarations of war and peace as well as troop deployments or operations, the dearth of strategically meaningful jurisprudence on sections 15, 91(7), 117 and also 118 - the only sections of the 1867 Act that explicitly reference the military instrument-is, despite the aforementioned protestations of the late great Bora Laskin, far from crippling to a proper constitutional understanding of the potency of Canada's military instrument. [To be fair, Laskin was probably seeking simply to better understand the legislative contours of the instrument per section 91(7). For strict strategic purposes, it is section 15, plus the more general regal executive power in the said section 9, and, hovering above and beyond these sections, the royal (executive) prerogative, that are most important.] Indeed, this dearth of jurisprudence may also betray the basic fact that Commonwealth courts have historically presumed, and to this day for the most part continue to presume, that foreign and military mattersquestions of so-called 'high policy' - are generally non-justiciable; that is, they do not lend themselves to the judicial process, and that the executive is institutionally more legitimately placed to dispose of these issues.

In Aleksic v. Canada ${ }^{38}$, for instance, the Ontario Superior Court of Justice held that tort claims against the Government of Canada for damage incurred during the 1999 NATO bombing of Yugoslavia in the Kosovo campaign were non-justiciable precisely in virtue of the fact the decision to bomb and the targets of the bombing were purely matters of high policy_just as would have been the historic Canadian decision to join the NATO alliance or any military alliance, for that matter. ${ }^{39}$ However, what

\footnotetext{
${ }^{38}$ Aleksic v. Canada (2002), 215 D.L.R. (4th) 720.

${ }^{39}$ Even if the issue were justiciable, the Crown would be immune by virtue of the fact that the bombing decision was one of so-called pure policy, as well as by virtue of section 8 of the Crown Liability and Proceedings Act, which strategically immunizes the Crown from tortious liability "in respect of anything done or omitted in the exercise of any power or authority exercisable for the Crown, whether in time of peace or war, for the
} 
was justiciable - and the Court here built on the innovative holding almost a decade earlier in Operation Dismantle - was subject matter that lay at the intersection of such high policy and Charter rights; in the event, the claims that the bombing campaign violated the plaintiffs' section 7 (life, liberty and security of the person) and section 15 (equality and nondiscrimination) rights. Relying on the precedent in Operation Dismantle, discussed in greater detail immediately below, the Court dismissed the Charter claims, with Justice Heeney declaring that "[t]o hold otherwise would permit any citizen to, in effect, hijack Canadian foreign policy.”

In Operation Dismantle, what had been challenged was a decision by the Canadian government to allow the testing of American cruise missiles on Canadian territory - testing that was alleged to have been in violation of section 7 of the Charter on the grounds, or so the argument went, that by hosting the missiles on Canadian soil, the Government of Canada had increased the risk of war involving Canada. Justice Wilson wrote in that decision:

The government's decision to allow the testing of the U.S. cruise missiles in Canada, even although an exercise of the royal prerogative, was reviewable by the courts under $\mathrm{s}$. 32(1)(a) of the Charter. It was not insulated from review because it was a 'political question' since the Court had a constitutional obligation under s. 24 of the Charter to decide whether any particular act of the executive violated or threatened to violate any right of the citizen.

In the end, the Supreme Court ruled in Operation Dismantle that there was no violation of section 7 of the Charter, not least because it determined that there must be a strong presumption that government action of a stateto-state nature that is not directed at, or that only incidentally affects, a particular Canadian was never intended to be captured by section 7-or by any other Charter right, for that matter. Although opening the door for more Charter actions on strategic questions (see below), particularly those touching individual rights, the Court's ruling, for all practical intents and

purpose of the defence of Canada or of training, or maintaining the efficiency of, the Canadian Forces.” 
purposes, actually concretized the dominance of the royal prerogative in respect of the military instrument. ${ }^{40}$

Aleksic treated, somewhat parenthetically, the question of whether the Charter applies to activities outside the territorial limits of Canada. The Court, relying on its earlier holding in $\operatorname{Cook}^{41}$, held that, conditionally, it did. The Cook ruling was, however, eclipsed, not uncontroversially, by $H_{a p e}{ }^{42}$, which provided for a two-part test to determine when there was extraterritorial applicability of the Charter: first, the conduct at issue has to be that of a Canadian state actor caught by section $32(1)^{43}$ of the Charter, and second, pursuant to international comity, the foreign state on whose territory the conduct occurs has to give its consent to the extraterritorial application of Canadian Charter or constitutional rights. The latter could evidently be presumed to be a formidably improbable condition, thereby reasserting the general immunity of military matters,

${ }^{40}$ We should add that in the hypothetical event that military activity of the Canadian government under the prerogative should be found to be in violation of a Charter right, there is evidence to suggest that this violation would likely be saved under section 1 of the Charter, which reads that the rights and freedoms in the Charter are "subject to such reasonable limits prescribed by law as can be demonstrably justified in a free and democratic society." In obiter, in the Operation Dismantle case, Justice Wilson mused that were the government to impose conscription for overseas service in wartime, this would seem to be in violation of section 7 of the Charter, but would meet the reasonable limitation in section 1. Contrariwise, she supposed, a government decision to seize citizens for military service without enabling legislation would unequivocally violate the Charter, under both sections 7 and 1 .

${ }^{41}$ R. v. Cook , [1998] 2 S.C.R. 957. The Supreme Court held that a Canadian citizen questioned abroad is still entitled to Charter protection as long as the application of the Charter does not interfere with the sovereign authority of the foreign state in question; more precisely, as long as there is no objectionable interference with the exercise of the foreign state's jurisdiction.

${ }^{42}$ R. v. Hape (2007), 280 D.L.R. (4th) 385.

${ }^{43}$ Section 32(1) specifies that the Charter applies (a) to the Parliament and government of Canada in respect of all matters within the authority of Parliament [...]; and (b) to the legislature of each province in respect of all matters within the authority of the legislature of the province. Section 32(1) does not provide for an explicit territorial limit on the application of the Charter. 
and indeed the royal prerogative in relation to military matters, from judicial control. It is highly noteworthy, therefore, that the Supreme Court, in a unanimous recent decision, qualified this improbable applicability of the Charter in Khadr ${ }^{44}$, stating that the Charter applied to Canadian officials "to the extent that the conduct of Canadian officials involved [Canada] in a process that violated Canada's international obligations." This important holding, however, surely demands rapid clarification, as it greatly muddies the erstwhile clear, prerogative-laden marge de manoeuvre of Canadian officials acting abroad in complex operations, the international legality of which is not always within their control, or indeed not always decisive in Canadian calculations in respect of where the state's strategic interests lie. For instance, returning to Aleksic, could one not have argued, on the logic of Khadr, that the Kosovo war was illegal at international law (ius ad bellum), and that the consequent activities of Canadian troops and officials in Kosovo were contrary to the Charter? Or that Canadian intelligence agents collecting information on threats emerging from Iraq during the arguably illegal war in Iraq (also in terms of ius ad bellum) might be at risk of acting in contravention of the Charter? Affirmative answers to these counterfactual queries would surely be tantamount to meaningfully circumscribing some of the strategic potency of Canada's military and diplomatic instruments in the world.

The recent Amnesty International ${ }^{45}$ decision, issued prior to Khadr and thus relying on Hape, affirmed that the Charter did not apply to the conduct of Canadian Forces personnel in detaining or transferring Afghan

${ }^{44}$ Canada v. Khadr, [2008] S.C.J. No. 28. The Supreme Court found that section 7 of the Charter, relating to "fundamental justice," was engaged in this case, thereby imposing "a duty on Canada to provide disclosure of materials in its possession arising from its participation in the foreign process [i.e. the questioning of Omar Khadr at Guantanamo Bay] that is contrary to international law and jeopardizes the liberty of a Canadian citizen." This important determination was in fact somewhat anticipated by Justice LeBel's reasons for the plurality in Hape, where he noted at paragraph 101: "I would leave open the possibility that, in a future case, participation by Canadian [state actors] in activities in another country that would violate Canada's international human rights obligations might justify a remedy under s. 24(1) of the Charter [...].”

${ }^{45}$ Amnesty International v. Canada, 2008 F.C. 336. 
detainees; that is, even though the Forces were clearly Canadian state actors, the application of Canadian constitutional rights to their detainees was not consented to by the Afghan government. So while the question, which lay at the intersection of the prerogative and a claimed constitutional right, was easily justiciable, this mattered little in practice, as the effective marge de manoeuvre of the Canadian Forces in Afghanistan was unaffected by the decision. ${ }^{46}$ This decision is now being appealed before the Federal Court of Appeal, and the decision in this appeal will surely consider Khadr. En attendant, it must be posited, although perhaps controversially, that Charter considerations, as a general rule, continue to matter little in strategic decision-making by the military in Canada. Khadr notwithstanding, the Charter, in other words, is for the time being not a very material bar to Canadian strategic power, as manifested by the military, at least outside Canadian borders.

Of course, as already established, in addition to the courts interpreting or controlling, through the common law, the scope of the prerogative in strategic matters, legislation may also clip or eclipse the prerogative. The National Defence Act, for instance, governs, on the strength of the federal militia power in section 91(7) of the 1867 Act, the conduct of the Canadian Forces and the administration of the Department of National Defence. And to the extent that the provisions of the Act speak explicitly or by necessary implication to matters otherwise coming under the purview of the royal prerogative, the legislative provisions, under the constitutional doctrine of parliamentary supremacy, trump the prerogative. Notably, section 31 of the Act provides for "active service” designation by the Governor in Council (the executive or government), which may seem

${ }^{46}$ In Amnesty International, Justice Mactavish, in obiter, suggested that there remains some uncertainty in respect of the possibility that the military, because of its coercive character, might require a sui generis test for extraterritorial application of the Charter. In this respect, Mactavish tracks the important British holding in Al-Skeini et al. v. Secretary of State for Defence, [2007] UKHL 26, in which it was determined that the UK Human Rights Act, 1998, which effectively implemented into British domestic law the European Convention on Human Rights, did apply to British public authorities-in the event, the British military-to the narrow extent that they exercised effective control on foreign territory through military detention facilities, as with embassies and consulates, operating on the consent of the Iraqi government. Strangely, Al-Skeini is not at all referenced in Amnesty International or in the cognate Canadian jurisprudence in Cook, Hape or Khadr. 
to muddy the waters of the historically untouchable royal prerogative in respect of troop deployments. In practice, however, it seems that, at least for the time being, this provision has not generally been viewed or treated as a statutory rule in respect of deployment of the Canadian Forces. ${ }^{47}$

In the meantime, section 32 of the Act states that "Whenever the Governor in Council places the Canadian Forces or any component or unit thereof on active service, if Parliament is then separated by an adjournment or prorogation that will not expire within ten days, a proclamation shall be issued for the meeting of Parliament within ten days, and Parliament shall accordingly meet and sit on the day appointed by the proclamation, and shall continue to sit and act in like manner as if it had stood adjourned or prorogued to the same day." This provision clearly adds a perfunctory measure of legislated Parliamentary involvement in at least the discussion of military matters, broadly put, at the expense of the royal prerogative. However, this means that Parliament is only strictly required to meet and sit after a given declaration of war or troop deployment and, given the absence of specific language to that effect, without a legal mandate for scrutiny, let alone control, of strategic or tactical operations of the Forces. Moreover, considering that the weight of the evidence continues to suggest that there is no constitutional requirement for Parliament to debate or vote, ex ante, on Canadian declarations of war of troop deployments, the prerogative for the military instrument clearly emerges unmolested-in strategic terms, at least. ${ }^{48}$

${ }^{47}$ Craig Forcese, National Security Law (Toronto: Irwin Law Inc., 2008), p. 154. See, however, the dissent in Aleksic, supra note 38, by Justice Wright, suggesting that the active service provision in the National Defence Act should now be seen as having replaced the royal prerogative for military deployments.

${ }^{48}$ See the idiosyncratic piece by Ikechi Mgbeoji who, although searching long and hard through Hansard records for such a constitutional requirement for parliamentary oversight or debate on international troop deployments, concedes that no such requirement exists in Canadian law. (However, there may be evidence of a vague or indeed very embryonic constitutional convention in this respect, with which, one could add, the interest of the last and current Conservative governments in parliamentary voting on treaties, declarations of war and peace, as well as troop deployments, is ostensibly consistent.) He does, however, suggest that while "the Crown prerogative on matters of war remains intact, albeit with some modicum of judicial inroads," (p. 183), jurisprudence around this prerogative remains unclear, and some statutes, such as the National Defence Act, may have laid the groundwork for future judicial inroads into the 
Provincial considerations do not figure prominently or obviously in most elements of the strategic military instrument. They are important, however, in respect of various permutations of Canadian military deployment or so-called 'call-out' on Canadian soil. Classically, the Canadian Forces may be called out in aid of the civil power, which is governed by Part VI of the National Defence Act. This aid of the civil power involves the prevention or suppression of an anticipated or actual riot or disturbance of the peace that is deemed by the relevant provincial attorney general as exceeding the capabilities of provincial civilian authorities. This call-out may be requisitioned in writing by the relevant provincial attorney general, following which, according to section 283 of the Act, "[t]he Canadian Forces or any part thereof called out in aid of the civil power shall remain on duty, in such strength as the Chief of the Defence Staff or such officer as the Defence Staff may designate deems necessary or orders, until notification that the Canadian Forces are no longer required in aid of the civil power is received from the attorney general of the province concerned and, from time to time as in the opinion of the Chief of the Defence Staff the exigencies of the situation require, the Chief of the Defence Staff may increase or diminish the number of officers or non-commissioned members called out."

The federal government may equally trigger the domestic deployment of Canadian Forces without the provinces. This includes the ill-defined "public service" deployments under the National Defence Act in respect of a law enforcement matter that, according to section 273.6(2) of the Act, (a) is in the national interest (a term of art evidently undefined in the legislation, and therefore subject to executive discretion), and (b) cannot be effectively dealt with except with the assistance of the Canadian

prerogative. [Ikechi Mgbeoji, "Prophylactic Use of Force in International Law: The Illegitimacy of Canada's Participation in 'Coalitions of the Willing' Without United Nations Authorization and Parliamentary Sanction” (2003) 8:2 Rev. Const. Stud. 170.] It is also somewhat noteworthy that the National Defence Act, at a largely sub-strategic level, replaces the Criminal Code of Canada in respect of military justice and discipline as these concern members of the Canadian Forces both at home and abroad. In either scenario, federal legislative supremacy-whether under the militia or criminal law power-remains unaffected. 
Forces. $^{49}$ More fundamentally, however-and this gets to the core of the federal state's constitutional capabilities in respect of strategic domestic deployment-, any threat or emergency (or indeed attack) emanating from, or materially related to, foreign states or parties could (and likely would, depending on its assessed scale) be addressed under the Emergencies Act (not the aid of the civil power provisions), including through the declaration of a public order, international or war emergency-again, depending on the details of the matter at hand. The Emergencies Act, which we take up in the next section, triggers a host of potent government capabilities and assets, including the military instrument. Moreover, as we argue below, the entirety of the ambit of this military instrument afforded by the royal prerogative in the context of strategic emergencies-domestic or international-is not exhausted or replaced by this Act.

The provinces also loom large in respect of section 117 of the 1867 Act, which states that "[t]he several Provinces shall retain all their respective Public Property not otherwise disposed of in this Act, subject to the Right of Canada to assume any Lands or Public Property required for Fortifications or for the Defence of the Country." This is a powerful expropriation provision for the federal government, affirmed most recently in the Human Rights Institute ruling ${ }^{50}$ in 2000, which upheld the Government of Canada's right to expropriate land from British Columbia for purposes of continuing a torpedo testing arrangement with the United States near Nanoose Bay. While section 117 is an executive power (not a legislative power), its strategic force is similar to that of the non-military

${ }^{49}$ Forcese, supra note 47 at pp. 168-170, observes that two federal orders-in-coucil were issued in the 1990s, pursuant to the royal prerogative, in relation to domestic deployment of the Canadian Forces solely on the initiative or approval of the federal government: the first, the Canadian Forces Assistance to Provincial Police Forces Directions (P.C. 1996833), addresses federal military assistance to provincial law enforcement agencies; the second, the Canadian Forces Armed Assistance Directions (P.C. 1993-624), addresses the deployment of Canadian special forces assets. Both orders-in-council address disturbances of the peace, likely or actual, deemed of national interest. Notes Forcese at p. 170: "Out of an abundance of caution, [...], the preferable approach is to treat the order-in-council provisions as procedures governing the application of the [National Defence Act] public service powers to the particular circumstances to which they relate."

${ }^{50}$ Human Rights Institute of Canada v. Canada, [2000] 1 F.C. 475. 
[VoL. 05 No. 01

declaratory power (a legislative provision) in the 1867 Act's section 92(10)(c), which we discuss in the next section, and it overcomes the general presumption of provincial land (and resource) ownership outlined in section 109. To be sure, of course, the Government of Canada may enact laws under section 91(7), the militia power, that have the very same effect as section $117 .{ }^{51}$

Section 109 is in fact a key strategic section for purposes of the natural resource factor of power, which we examine two sections hence. Along with national economic capacity and population, both also discussed in upcoming sections, the natural resources factor greatly influences Canada's military instrument (and indeed the diplomatic instrument) through avenues that are generally indirect. And, of course, these factors of power are greatly complicated by the federalism dynamic, which means that the strategic military instrument, while prima facie dominated by the federal executive, is in reality undergirded by highly nuanced federalprovincial constitutional dynamics.

\section{Government, Or Pure Executive Potency}

If the strategic capacity of the Canadian state, constitutionally speaking, is significant in the purest terms of its diplomatic and military instruments - and this, let us recall, in spite of the astrategic design and strategically indifferent interpretation of the Constitution-then these instruments are only buttressed, as a rule, by other 'subsidiary' strategic elements of the Constitution having strategic import. Perhaps the most important of these subsidiary strategic elements is the general potency, flexibility or efficiency, broadly conceived, of the federal executive. (Let us recall that in Canadian constitutional law, executive power follows the grant of legislative power. And, as mentioned above, given the frequent identity between the executive and legislative branches in the context of majority governments in Westminster systems—-party discipline oblige-,

${ }^{51}$ Gérard La Forest, infra note 79 at p. 155, affirms this on the strength of the 1874 holding in L'Union St. Jacques de Montréal v. Bélisle (1874), 6 P.C. 31. The age of the case likely speaks less to the import of the ruling itself than to the aforementioned patent penury of cases on the strategically important militia power. 
a given federal legislative power should more often than not be seen as indicative of a concomitant executive power. The reverse is evidently often not true.)

The emergency powers or capabilities of the federal Parliament (by implication, the federal executive) are perhaps the most obvious manifestation of the link between pure executive potency and strategic power. On this matter, the remarks of Craig Forcese are instructive:

There will $[\ldots]$ be threats so far in excess of the normal state of and so immediate that the state will treat them as emergencies. Such a state of emergency may change the institutional structure within which [...] law operates. [...] [D]emocracies are built on a system of checks and balances that constrain the exercise of power. Yet, emergencies often, if not usually, require the exercise of power. Moreover, this power must be implemented swiftly and with resolution. While law applicable in normal situations diffuses power, emergencies concentrate it. ${ }^{52}$

Historically, the general or residuary power to make laws for the peace, order and good government (POGG) of Canada under section 91 in the 1867 Act has provided the most apparent constitutional underpinning for federal legislation and actions in cases of emergencies, including war or threats of war. ${ }^{53}$ This broad emergency power (or, technically, the emergency branch of the POGG power), invoked by the federal government in proclaiming the War Measures Act in the 1970 October Crisis, has since arguably been discliplined to a great extent by legislation in the form of the Emergencies Act, 1988. (The War Measures Act was repealed in 1988.) The Emergencies Act defines "national emergency" in section 3 as "an urgent and critical situation of a temporary nature that (a) seriously endangers the lives, health or safety of Canadians and is of such proportions as to exceed the capacity or authority of a province to deal

\footnotetext{
${ }^{52}$ Forcese, supra note 47.

53 The leading case in this regard is Reference Re. Anti-Inflation Act, 1975, [1976] 2 S.C.R. 373.
} 
with it, or (b) seriously threatens the ability of the Government of Canada to preserve the sovereignty, security and territorial integrity of Canada." This definition makes clear that certain temporary-although prima facie sweeping-executive emergency measures are essential, in certain situations, to restore the capacity of the government to pursue strategic interests - in the event, described as sovereignty, security and territorial integrity. These measures ("orders and regulations"), depending on the nature of the declared emergency, include everything from prohibitions on travel to requisition or seizure of property, control of specified industries and removal from Canada of non-citizens. [Some of the Act's orders and regulations clearly coincide with the federal quarantine power under section 91(11) of the 1867 Act. The limits of this power have not to date been properly established by the jurisprudence, even if the Canadian SARS emergency of 2003 gave it new strategic relevance.] The Act proposes four possible categories of national emergency, each of them with a certain strategic import: public welfare, public order, international or war, respectively with (renewable) expiry dates of ninety, thirty, sixty and one hundred and twenty days. Moreover, the Act requires nonbinding "consultation" between the federal executive and affected provinces prior to a declaration, on "reasonable grounds," by the former of a national emergency under the auspices of the Act, as well as ex-post parliamentary supervision of the declaration and associated temporary special measures taken by the executive to deal with the emergency. (Tracking the logic of the federal defence aid of the civil power provisions, the federal government may not, in the case of a public welfare or public order emergency where the direct effects of the emergency are confined to, or occur mainly in, a single province, declare an emergency in the absence of affirmation from the lieutenant-governor of the concerned province that management of the matter at hand exceeds the capabilities of the province.) Parliament has, in a similar vein, the authority to revoke a declaration of emergency. Federalism oblige, the Act states that federal orders and regulations made under its auspices may not "unduly impair the ability of any province to take measures [...] for dealing with an emergency in the province” or, in respect of command and control, that nothing in the Act should be construed or applied "so as to derogate from [...] the control or direction of the government of a province or municipality over any police force over which it normally has control or direction.” 
As the Act has never to date been invoked by the federal government to deal with an emergency, we do not yet know the extent to which it in practice circumscribes, or indeed channels, executive power under the emergency branch of the POGG power in dealing with patently strategic issues like military or national security threats. Some have suggested that while, in practice, “Parliament's constitutional authority to respond to emergencies cannot be defined by, or made to conform to, the terms of an ordinary statute, the definitions of emergencies found in the Emergencies Act would surely be relevant in any future constitutional litigation involving use of the emergency branch of POGG."54 This would seem to suggest that any litigation on an emergency-naturally slow off the mark-would typically occur after the response of Parliament (or government) to the emergency, swiftness of executive response oblige, and as such would have limited opportunity to circumscribe, in real-time, the emergency response of government-thereby requiring government instead to justify its response ex post. Nonetheless, as is often the case, and depending on the gravity of the strategic emergency in question, it is conceivable, if not probable, that the government's response would be conditioned in part by such expected litigation, thereby affirming somewhat the controlling power of the legislation. (Of course, it bears mentioning that the Emergencies Act is, as with all statutes, and as is explicitly mentioned in its preamble, constitutionally controlled the Charter. Moreover, it may be offered that the very fact that the Act does not in and of itself provide for any derogation whatever from the Charter in some sense makes it fairly tame emergency legislation.)

For all practical intents and purposes, of course, legislation is, after all, only legislation. It may be so significant as to be quasi-constitutional on a broad conception of the Constitution, but it is not strictly constitutional in status. As such, one could reasonable argue that the gap between what is strictly permitted in or by the Emergencies Act and what is constitutionally permissible is identifiable with an emergency (royal) prerogative enjoying constitutional status. This prerogative hovers over and above of the Emergencies Act, and is supported by cases such as Burmah Oil Co. v. Lord Advocate ${ }^{55}$, affirming the constitutional right of the executive to

\footnotetext{
${ }^{54}$ Patrick Monahan, supra note 13, p. 257.

${ }^{55}$ Burmah Oil Co. v. Lord Advocate, [1965] A.C. 75.
} 
defend the sovereignty of the country. Suresh, on perhaps a more micro level, referring as it does to "extraordinary circumstances" (yet to be defined), also intimates the existence of such a prerogative. ${ }^{56}$ And this emergency prerogative could effectively be viewed as embodying the contested doctrine of constitutional necessity, affirmed in Re Manitoba Language Rights ${ }^{57}$, where necessity is occasioned by extraordinary strategic circumstances (such as an overwhelming military or terrorist threat or attack, or in the Manitoba Language Rights case, a massive legal vacuum) requiring extraordinary or even ordinarily 'illegal' measures to protect or preserve the state. Such extraordinary measures would be strictly within the Canadian constitutional framework, with the "principle of necessity [viewed] either as an autonomous source of law or as a metarule of constitutional construction."58 In short, the necessity doctrine confirms that the Canadian Constitution cannot, in exceptional circumstances or emergencies, properly or reasonably be viewed as a 'death pact,' as it were, for the state and its citizens.

${ }^{56}$ Suresh v. Canada, [2002] 1 S.C.R. 3. At paragraph 78, the Court stated: "We do not exclude the possibility that in exceptional circumstances, deportation [under the then Immigration Act] to face torture might be justified either as a consequence of the balancing process mandated by s. 7 of the Charter or under s. 1." The Court goes on to say that a violation of s. 7 will be saved by s. 1 "only in cases arising out of exceptional conditions, such as natural disasters, the outbreak of war, epidemics and the like." This last bit seems to speak to the existence in Canadian constitutional law of the doctrine of necessity, discussed in the next note (57).

${ }^{57}$ Re Manitoba Language Rights, [1985] 1 S.C.R. 721. Said the Court in the unanimous judgment: "Necessity in the context of governmental action provides a justification for otherwise illegal conduct of a government during a public emergency. In order to ensure rule of law, the Courts will recognize as valid the constitutionally invalid Acts of the [Manitoba] Legislature." In the event, these constitutionally invalid laws were ones that had not been translated into French.

58 Oren Gross and Fionnuala Ni Aolain, Law in Times of Crisis: Emergency Powers in Theory and Practice (Cambridge, UK: Cambridge University Press, 2006), pp. 46-47. For an interesting normative treatment of necessity, see David Dyzenhaus, The Constitution of Law: Legality in a Time of Emergency (Cambridge, U.K.: Cambridge University Press, 2006). Strictly speaking, the ruling in the Manitoba Language Rights Reference, supra note 57, affirms the doctrine of necessity not as a proper principle of the Canadian Constitution, but rather as subservient to the constitutional principle of the rule of law. 
At a strictly constitutional level, therefore, we again have the character and scope of pure Canadian strategic power-in this case, executive potency as manifested in emergencies-being most meaningfully defined at the intersection of the royal (emergency) prerogative and Charter rights. This dynamic is complicated, though, by the fact that the Charter has nothing explicit to say regarding emergencies per se. It does, as we know, provide in section 4(2) that "[i]n time of real or apprehended war, invasion or insurrection, a House of Commons may be continued by Parliament and a legislative assembly may be continued beyond five years if such continuation is not opposed by the votes of more than one-third of the members of the House of Commons or the legislative assembly, as the case may be." 59 Naturally, there having been no "apprehended war, invasion or insurrection" in Canada from well before the advent of the Charter, this provision has neither been invoked by the executive nor treated in the jurisprudence. We do know, however, that it provides, if necessary, for legitimate constitutional extension of executive power in times of strategic import. Again, this speaks to strategic power as capacity, not exercise, as such a move would doubtless prove politically contentious and, as with declarations of emergency under the Emergencies Act, could well be subject to judicial action after the fact. ${ }^{60}$

${ }^{59}$ This provision, in 1982, replaced virtually identical language, now repealed, in part of section 91(1) of the Constitution Act, 1867. Interestingly, section 91(1) had been added to the Constitution in 1949, a time at which the Government of Canada would clearly have had strategy, in one form or other, on its mind.

${ }^{60}$ Back in 1985, J.R. Mallory wrote: "The first provision [of the Constitution Act, 1982, that may give rise to constitutional challenges on procedural grounds] is subsection 4(2) [...]. This is clearly a case where a court might have to inquire what Parliament actually was for this purpose.” [J.R. Mallory, "Beyond 'Manner and Form': Reading Between the Lines in Operation Dismantle Inc. v. R.” (1985) 31 McGill L.J. 480. Forcese, supra note 47, observes that it is not at all clear how and with what degree of activism s. 4(2) would be policed by the courts. Would, for instance, courts review, or be capable of meaningfully reviewing, the alleged existence of real or apprehended war, invasion or insurrection? He is also inclined to believe, as I noted above, that courts could well be disposed to save breaches of a number of Charter sections, section 7 in particular, under section 1. Drawing, therefore, on the holding in Re. Gray (1918), 57 S.C.R. 150, Forcese hints here at an eventual, constitutionally required role for Parliament in checking executive emergency activities, noting at p. 120 that "a Parliament tempted to delegate indefinitely its full plenary powers, perhaps in response to an emergency, would [...] run 
The Charter also has a powerful notwithstanding clause (section 33) providing for the operation of laws by either the federal Parliament or provincial legislatures notwithstanding certain sections of the Charter. This clause has not to date been invoked by any federal government, and would not be operative on the 'democratic rights' in sections 3, 4 and 5, as well as the "mobility rights," discussed later in this piece, in section 6 . However, in the event of an emergency, national security or military event, the federal government would have available to it, under the notwithstanding clause, the capacity to override the Charter "legal rights" in sections 7 to 14, as well as the equality provision in section 15. (No justification for such an override would have to be provided under section 1 , as that section would also be overridden by section 33.) It is also not inconceivable, depending on the gravity of the circumstances, that a government, confronted with a "real or apprehended war, invasion or insurrection," could invoke both the notwithstanding clause and section 4(2), which would be tantamount to a fairly potent cocktail of executive override of most of the Charter's key rights provisions. ${ }^{61}$

It behooves us to note, furthermore, that the POGG power has at least one additional 'branch' or dimension, outside of the said emergency branch, that has strategic import. The 'national concern' branch ${ }^{62}$ is seldom used by government and still not very clearly or persuasively defined in the jurisprudence. It is also approached by the courts with considerable reticence, preoccupied as has been Canadian jurisprudence

afoul of a long-established pre-Charter constitutional restriction barring complete abdication of Parliament's responsibility in favour of the executive.”

61 Of the first fifteen Charter rights, considered the key bulwark of Canada's constitutionalized fundamental rights and freedoms, only sections 5 (that Parliament will sit at least once every twelve months) and 6 (mobility rights) would effectively be saved under this cocktail. Sections 3 (that every citizen has the right to vote in an election) and 4(1) (that no House of Commons will continue for more than five years) would become moot upon the invocation of section 4(2).

62 Some scholars, such as Monahan, have pointed to a fourth possible-although embryonic - branch of the POGG power relating to interprovincial concerns or matters of interprovincial significance. 
over most of the country's constitutional history with the POGG power either as a residual or emergency power. Still, one can presume the emergence of certain new strategic matters (not emergencies) characterized by "a singleness, distinctiveness and indivisibility." ${ }^{33}$ These matters would not have existed or been anticipated at the time of Confederation, or would over time have become a national concern (and therefore would fall under federal jurisdiction), even if originally under provincial jurisdiction. Such new strategic matters could eventually expand the strategic jurisdiction and therefore power of the federal government. Ostensibly strategic matters like nuclear energy have in the not too distant past been justified as falling under federal jurisdiction on the basis of this national concern branch. ${ }^{64}$ Indeed, the strategic import of uranium was recognized by the federal government immediately after the explosion of the first atomic bombs toward the end of the Second World War; the Government of Canada availed itself of the highly potent yet little known declaratory power in section 92(10)(c) of the 1867 Act, which provides that the federal Parliament may declare certain local works or undertakings, although wholly situated within or otherwise falling under the jurisdiction of a province, as for the "general advantage of Canada." Such a declaration would mean that the declared 'work' (that is, the work declared in legislation) would immediately fall under federal jurisdiction.

This declaratory power has been used nearly five hundred times since Confederation, in particular in the transportation industry, and especially in respect of the once highly strategic (and still arguably somewhat

${ }^{63}$ See R. v. Crown Zellerbach Canada Ltd., [1988] 1. S.C.R. 401. See the critical counterpoint by Brun and Tremblay, supra note 24 at pp. 556-557, in which they wrily note: «Inutile de dire qu'il n'existe pas dans la jurisprudence de préoccupation correspondante de transférer aux provinces les matières, dont les exemples ne manquent pas, qui étaient à l'origine d'intérêt national et qui sont devenues de nature purement locale et privée. »

${ }^{64}$ Ontario Hydro v. Ontario, [1993] 3 S.C.R. 327. Of course, given the security and military considerations associated with nuclear energy, including the need for energy production and secure nuclear energy sites in the event of war or insurrection, and given the magnificent size of Canada's uranium reserves and exports, it stands to reason that this was a strategic coup for the federal government. 
strategic) rail sector, but also in respect of telecommunications and labour strikes of national significance. A declaration by Parliament is dispositive, meaning that courts will not enquire into whether the 'work' - say, a uranium mine-in question, provided it relates to something physical, material or tangible, is actually for the general advantage of Canada. ${ }^{65}$ Signally, when the federal government declared atomic energy for the general advantage of Canada in 1946, it also enacted the Atomic Energy Control Act. As this legislation was contested, because of traditional provincial dominance in the area of natural resources (to which we next turn), the immediate use of the declaratory power by the federal Parliament effectively eliminated any uncertainty as to the legitimacy of the legislation and federal jurisdiction until such time as the Supreme Court, many years later, in the 1993 Ontario Hydro case ${ }^{66}$, could confirm the statute on the basis of the national concern branch of the POGG power. 67

Finally, and critically, Canadian strategic potency is doubtless buttressed by the conspicuous fact that the criminal law power resides with

${ }^{65}$ See Jorgenson v. Canada, [1971] S.C.R. 725. Contrast this holding with that in the famous 1952 U.S. Steel Seizure case, Youngstown Sheet \& Tube Co. v. Sawyer, 343 U.S. 579, in which the U.S. Supreme Court decided that a seizure by the President (the federal executive branch) of a steel mill—strategically important for purposes of military production during the 1950-53 Korean war-was unconstitutional, as it was contrary to the separation of powers doctrine requiring that legislation in respect of such a seizure sit with Congress (the legislative branch).

${ }^{66}$ Supra note 64.

${ }^{67}$ Monahan, supra note 13, p. 371. For an expansive and indeed critical treatment of the declaratory power, see Andrée Lajoie, Le pouvoir déclaratoire du Parlement: Augmentation discrétionnaire de la competence fédérale du Canada (Montréal: Les Presses de l’Université de Montréal, 1969). Exotically, Lajoie proposes at the end of his book that the fact that 7/8 of the uses to date of the declaratory power have related to the rail sector betrays a conspiracy by Macdonald at Confederation not to explicitly regulate intraprovincial railways in the formal division of powers of the 1867 Act, but rather through the insertion of the prima facie innocuous and inconspicuous section 92(10)(c). Strategy! Writes Lajoie at p. 112: « Ce n’est pas impossible si l’on considère la structure économique du Canada à la fin du XIXe siècle, de ce pays où des centaines de compagnies ont construit chacune une parcelle de ce qui n'allait devenir un réseau à l'échelle canadienne que beaucoup plus tard. » 
the federal government. Section 91(27) of the 1867 Act states that the federal government has responsibility for "[t]he Criminal Law, except the Constitution of Courts of Criminal Jurisdiction, but including the Procedure in Criminal Matters.” [The administration and enforcement of justice, for its part, including the establishment and maintenance of provincial police forces and courts, lie with the provinces under section 91(14).] This federal criminal law power has, in general, been interpreted broadly by the courts, which have distilled three baseline factors that must generally underpin legitimate criminal laws - to wit, the existence of a prohibition on a given activity, the existence of an associated penalty and, lastly, that the legislation in question must serve a criminal public purpose, such as "peace, order, security, health, morality."68 (Contrast this with Australian and American constitutional treatment of criminal law, where substantive criminal law resides largely with the states, requiring considerable coordination of criminal law-making across the jurisdictions in the former case, and resulting in significant inconsistencies in substantive criminal law across the jurisdictions in the latter case.) Indeed, the criminal law power may ostensibly be used by the federal government to enact legislation relating to a large number of activities-economic activities, especially-that would typically have fallen under the provincial property and civil rights power when weighed against federal powers like the POGG and trade and commerce powers.

For our purposes, it is instructive that the broad federal criminal law power has strategic import in the peculiar context of Canadian national security. As a strategic concept, national security refers to the protection or critical Canadian assets and interests against a variety of threats, domestic and international, human and natural, deliberate and accidentala state of affairs that lies somewhere between the spheres of personal safety and international security. ${ }^{69}$ And on this conceptualization, national security can be said to have strategic import to the extent that it involves protection of critical Canadian assets and interests specifically against

${ }^{68}$ Justice Rand in Reference Re Validity of section 5(a) of Dairy Industry Act (Canada), [1949] S.C.R. 1.

${ }^{69}$ See Securing an Open Society: Canada's National Security Policy (Ottawa: Privy Council Office, 2004), p. 4 
foreign or foreign-related threats, whether manifested in Canada proper or abroad. Protection against these threats may well be provided in part by the diplomatic and military instruments of the state, but in general terms, it stands to reason that the provision of this national security, as a function of the executive potency factor, should be seen as a supporting (in some cases, 'defensive') condition for the proper functioning of these two instruments. At the federal level, the term national security or one of its cognates appears in at least thirty statutes, with less than a third of these attempting - with great difficulty-to define the term. ${ }^{70}$ Taken together, statutes like the Emergencies Act, Emergency Management Act, CSIS $\mathrm{Act}^{71}$, Royal Canadian Mounted Police (RCMP) Act, Security of Information Act (formerly the Official Secrets Act), Canada Evidence Act, Citizenship Act, Immigration and Refugee Protection Act ${ }^{72}$, Aeronautics

${ }^{70}$ Forcese, supra note 47, p. 8.

71 The CSIS Act is likely based on the federal POGG power or the defence power in section 91(7), based on the holding in Attorney-General (Quebec) v. Keable v. AttorneyGeneral (Canada), [1979] 1 S.C.R. 218. This holding concerned the activities of the precursor to CSIS, the RCMP's Security Service. (One could reasonably suppose that the POGG head of power, in point of fact, is far more plausible than the defence power as a support for the Act, given that the Act deals only parenthetically with defence interests.) More interestingly, one wonders why the provinces do not erect intelligence services of their own. Why, for instance, does Quebec, while profiting from the Sûreté du Québec (the provincial police force) under section 92(14) of the 1867 Act, not create its own version CSIS? Indeed, this was one of the prospective ('strategic') practical-cum-policy challenges or 'to do's' envisioned by the sovereigntist camp on the eve of the 1995 referendum on Quebec secession in the event of accession to proper statehood. Constitutionally speaking, the answer is relatively straightforward: Provincial spending power aside (which we take up in the section below on national economic might), the "within the province" limitation of section 92 (which also exists in sections 92A, 93 and 95) of the 1867 Act effectively limits the policing-cum-security activities of the provinces to their respective territory.

72 A prominent national security process found in the Immigration and Refugee Protection Act is the security certificate, which provides for detention and deportation of foreign nationals and permanent residents deemed to constitute a threat to the security of Canada. These provisions were ruled unconstitutional (variously contrary to sections 7, 9 and 10(c) of the Charter, and not saved by section 1) in Charkaoui v. Canada, [2007] S.C.J. No. 9. The declaration nullifying the certificate regime was suspended for one year. The federal government reenacted amended provisions in 2007, creating, inter alia, an amicus curiae regime for those detained under a security certificate. 
Act, Canadian Transportation Act and indeed, inter alia, the National Defence Act make up the nucleus of Canada's national security legislative framework. And for all practical intents and purposes, the leading strategic assets or agencies of the Canadian state in the national security sphere are the RCMP and CSIS. The former exists on the basis of the RCMP Act and the latter on the basis of the CSIS Act. However, national security, especially given its troubled susceptibility to precise legal definition, ${ }^{73}$ is in many important respects given constitutional salience and expression by federal criminal law. As such, a number of provisions of the Criminal Code of Canada are highly strategic. For instance, the Anti-Terrorism Act of 2001 amended the Criminal Code to define terrorism and created several offences related to terrorism (with significant extraterritorial effect), including terrorism financing and participation in, facilitation and execution of terrorist acts. ${ }^{74}$ The Act also provided, among other things, for the seizure and forfeiture of property within Canada belonging to terrorist groups.

Provisions related to two of the pivotal criminal law processes enacted in the Anti-Terrorism Act-so-called investigative hearings and recognizance with conditions, including preventive arrests in the context of potential terrorist acts-sunsetted in 2006. The federal government attempted to reinstate these provisions, without substantial amendment, in 2007 via Bill S-3. This bill was passed by the Senate, but was at second

73 See the exceptional effort by the Supreme Court to delimit "national security" in Suresh, supra note 56, in which the Supreme Court, referring to the then Immigration Act, stated with affirmation: "We reject the arguments that the terms 'danger to the security of Canada' and 'terrorism' are unconstitutionally vague.” Compare this with note 74 below.

${ }^{74}$ In R. v. Khawaja, [2006] O.J. No. 4245, the Ontario Superior Court of Justice found that the motive clause in the definition of terrorism contained in the Anti-Terrorism Act, which related to an act or omission "in whole or in part for a political, religious or ideological purpose, objective or cause”, was unconstitutional, as contrary to section 2 of the Charter (freedoms of conscience, religion, thought, belief, expression and association) and not saved by section 1 . Note also that, unlike the majority of Canadian laws, as with the terrorism provisions, the Criminal Code has a number of provisions with extraterritorial effect (e.g. hijacking, passport forgery, piracy and bigamy). The Security of Information Act, notably, has extraterritorial effect, in de facto 'criminal law' terms, in respect of the offence of espionage. 
reading in the House of Commons when it recessed in June 2008. An election was called in September 2008, and the bill has not been reintroduced at this time of writing.

Of course, we have already discussed the powerful executive expropriation power, for military purposes, in section 117 of the 1867 Act. We discuss the federal government's general expropriation powers in the next section on natural resources.

\section{NATURAL RESOURCES (AND FOOD)}

There is an intimate strategic relationship between the geographic element or factor of power-not explored per se in this piece because excessively abstract-and the less abstract natural resources factor. ${ }^{75}$

75 Of pure geography, abstraction oblige, and apart from the necessary delineation of physical (provincial, territorial and national) borders, there is precious little explicit language in the written Constitution. Having conceded this in principle, however, the Constitution is implicitly and doctrinally rich on the subject. One reasonable proxy for geographic power is the notion of territorial integrity or territorial sovereignty. Commenting tangentially, for instance, on the issue of offshore minerals, where the Supreme Court, in the B.C. Offshore Reference, [1967] S.C.R. 792, consistent with treatment of this matter in Australia and the United States, confirmed federal legislative jurisdiction and ownership rights over the territorial sea and federal legislative jurisdiction and exploitation rights over the continental shelf, Peter Hogg writes: "Where the Constitution Act, 1867 is not explicit on the status of offshore resources, it is noteworthy that all these powers affecting external sovereignty [emphasis added] that are mentioned [in the 1867 Act] are, without exception, confided to the federal Parliament. These include trade and commerce [s. 92(2)], military and naval service and defence [s. 91(7)], beacons, buoys, lighthouses and Sable Island [s. 91(9)], navigation and shipping [s. 91(10)], and other major offshore resources, namely, seacoast fisheries [s. 91(12)]. In all these matters, the Constitution Act, 1867 recognizes that once the low-water mark is passed, the international domain is reached. For domestic constitutional purposes, as well as for international law purposes, the actor in that domain is the federal government, not the provinces. [Peter Hogg, Constitutional Law of Canada, 4th ed., looseleaf (Toronto: Carswell), c. 30-10.] We might add that where the written Constitution and the courts are otherwise silent on the question of territorial sovereignty, the royal prerogative is in full effect, relating as it does to "the whole catalogue of relations [of the Crown] with foreign nations [including] sovereignty over land, sea, and air.” [F.A. Mann, Foreign Affairs in English Courts (Oxford: Clarendon Press, 1986), pp. 4-5.] 
Canada's physical geography not only provides a physical or spatial (and indeed psychological) barrier and buffer against conventional military or national security threats (so-called 'strategic depth'), and arguably a secure base for the prosecution of military campaigns abroad, but it is also a source of the many natural resources or raw materials that drive the country's industrial capacity. In addition, this land mass informs Canada's human holding capacity, which in turn feeds the national industrial capacity and provides direct manpower or talent for the diplomatic and military instruments that directly project Canadian strategic power. We discuss industrial capacity and population as factors of power, as reflected in the Constitution, in our final two sections below. For now, let us offer-indeed repeat-that what is most salient in analyzing the constitutional treatment of these factors of power, as well as natural resources, is not only the raw potential magnitude of the power in question (bearing in mind the distinction between theoretical constitutional potential and policy-political praxis), but also, critically, the extent to which this power may be mobilized for strategic purposes-or more readily, in the service of one or both of the state's diplomatic and military instruments.

Natural resources, in respect of which Canada has been called an apparent "superpower,",76 are critical to Canadian strategic power in at least three key respects. First and foremost, there is the need for adequate and secure supply of such resources for the Canadian population and the Canadian state-particularly its military and diplomatic instruments. Secure access to non-renewable resources like oil and gas, coal and uranium is evidently essential, to take but an obvious example, for purposes of energy production and consumption (and export), while access to renewable resources like forestry products is critical to construction, both for the general economy (a factor of strategic power) and for military purposes. Note the intervention by Hans Morgenthau in this respect, writing at the height of the Cold War:

76 Prime Minister Harper's speech of July 14, 2007, in the United Kingdom: http://www.ctv.ca/servlet/ArticleNews/story/CTVNews/20060715/g8_harper_060715?s_ $\underline{\text { name }=\& \text { no_ads }}=$ 
With the increasing mechanization of warfare, which since the industrial revolution has proceeded at a faster pace than in all preceding history, national power has become more and more dependent upon the control of raw materials in peace and war. It is not by accident that the two most powerful nations today, the United States and the Soviet Union, come closest to being self-sufficient in the raw materials necessary for modern industrial production, and control at least the access to the sources of those raw materials which they do not themselves produce. ${ }^{77}$

Similarly, food supply, on which we touch only very superficially in this paper, is also strategically relevant in the basic sense that an adequate, secure supply of such is critical to the survival of the population and the associated viability of the state's basic strategic instruments. Second, natural resources, if properly (some might say ruthlessly) levered, could in certain strategic scenarios be used as a national 'carrot' or 'stick' to advance Canadian interests. Targeted or earmarked export of certain resources, such as oil and gas, could arguably be exchanged for, or, in the diplomatic parlance, 'linked' to, the receipt by Canada of strategic advantages from another country or group of countries. Conversely, economic sanctions or natural resource export restrictions or prohibitions against targeted countries could be used by Canada to influence the behaviour of the countries in question. And third, there is the aforementioned vector connecting natural resources, renewable and nonrenewable alike, with the overall economic capacity of Canada, which in turn informs the potency of the state's military and diplomatic instruments. We touch briefly on some of this economic dimension at the end of this section, and leave for the next section our primary treatment of the constitutional connection between strategy and economy (or industrial might).

Questions of natural resource jurisdiction in Canada are complicated by the necessary dichotomy between ownership of natural resources and legislative power therefor. As a very general rule in Canadian constitutionalism, ownership of resources coincides with ownership of

\footnotetext{
${ }^{77}$ Supra note 25, p. 129.
} 
public lands. As such, in section 109 of the 1867 Act, which for all practical intents and purposes vests in the provinces all "lands, mines, minerals and royalties,"78 Professor (and later Supreme Court Justice) Gérard La Forest once remarked that the term 'lands' means public lands, and that the term 'public lands' "also includes the ordinary incidents to land. Thus it is clear that the word would be sufficient to include such mines and minerals as are ordinarily incident to land."79 This section, in jurisprudential terms, is typically regarded as a residuary or default section in relation to ownership of public lands and natural resources, with the dominant presumption (buttressed by the already discussed section 117) being that each province owns the lands and resources within its territorial limits unless these are captured by section 108, which enumerates in a schedule to the 1867 Act, specific "public works" and "property" in each province that are to be the property of Canada. (These include public harbours, lighthouses, rivers and lake improvements, and, as noted above, such strategic assets as military roads, so-called ordnance property, and armouries.) In the simplest terms, this means that the provinces, rather than the federal government, are, if they so desire, as in principle able to capture the lion's share of economic rents (in the form of royalties, mining taxes or bids on exploration) coming from the exploration and exploitation of resources on their lands. ${ }^{80}$ A notable exception here is offshore

${ }^{78}$ More precisely, the section vests public lands with the four founding provinces at Confederation. Equivalent treatment is effectively granted Manitoba, Saskatchewan and Alberta in the Constitution Act, 1930, and to the other provinces via their individual terms of union.

${ }^{79}$ Gérard V. La Forest, Natural Resources and Public Property Under the Constitution (Toronto: University of Toronto Press, 1969), p. 76.

${ }^{80}$ Note that rent capture tends to be more pronounced as a government objective in times of high natural resource commodity prices, as in the 1970s and indeed in the global commodity boom that immediately preceded this time of writing. Still, not all governments at all times will see rent capture as their primary policy objective, with some leaving instead the capture of rents to the private sector and seeing instead, as through much of Canadian history, the principal policy goal as consisting in natural resource development as a fillip to economic growth, as per the staple theory of economic development. Of course, this imperfect tension between rent capture and economic growth betrays a policy choice for governments. The constitutional capacity underpinning either option, however, does not in principle change. 
resources and, even more importantly, resources in Canada's three federal territories, all of which are owned by the federal government. ${ }^{81}$

The general presumption of provincial ownership of lands and resources is matched by general provincial legislative dominance in respect of natural resources. A number of subsections of section 92 have historically been at play here, but the critical section for strategic purposes over the last score of years has been section 92A, also known as the natural resource amendment, which was enshrined in the 1867 Act by the 1982

${ }^{81}$ Federal jurisdiction over the territories is constitutionally affirmed in the Constitution Act, 1871. The governance structures of each of the three territories - the Yukon, the Northwest Territories and Nunavut-is provided (quasi-constitutionally, as it were, on our conception of the Constitution), inter alia, by incorporating statutes bearing the name of the territory in question (e.g. the Nunavut Act, 1993). These acts include the results of some of the devolution, from the 1970s onwards, of many 'province-like' legislative powers to the territories - a process which has, in practical terms, mitigated, to a certain extent, some of the direct strategic power of the federal government in respect of the natural resources, economic and population factors of power. [The same is true of the several existing-although not constitutionalized-self-government agreements between the federal government and First Nations in the Yukon. See supra note 15.] Still, unlike in the provinces, with the exception of the Yukon, the federal government at present still collects all the royalties from territorial non-renewable resources-royalties which the federal government could then use in aid of the military and diplomatic instruments of the state.

Recognizing the dichotomy between constitutional capacity and policy-political praxiswell treated in this piece-, it is noteworthy that, in respect of offshore resources, the federal government has made a number of policy moves, such as the 2005 Offshore Arrangements, that have built on the 1985 and 1986 Offshore Accords that gave the governments of Newfoundland and Nova Scotia de facto ownership of offshore petroleum; that is, taxation of offshore resource revenues as if these resources were provincially owned. Note that in the Canada-Newfoundland Atlantic Accord Implementation Act, 1987, section 34(1) reads that "[w] $[\mathrm{w} e r e$ [...] a determination is made that self-sufficiency and security of supply do not exist, the Federal Minister has authority in relation to any fundamental decision [...] made during that period." Quaere: Is it not paradoxical, in strategic terms, that federal legislation should speak to federal suzerainty in respect of adequacy of domestic supply of petroleum in the context of an accord yielding to a province control of petroleum revenues, and yet not be able to otherwise speak, as a general rule, to such ongoing adequacy of domestic capacity in respect of petroleum revenues in any other context? 
Act. $^{82}$ Section 92A states that each province, within its territorial boundaries, has legislative responsibility for natural resources in respect of (a) intraprovincial exploration for non-renewable natural resources; (b) intraprovincial development, conservation and management (and, indeed, marketing) of non-renewable resources and forestry resources; as well as (c) development, conservation and management of intraprovincial sites and facilities for the generation and production of electrical energy; and that (d) each province may levy direct or indirect taxes relating to its natural resources. In practice, these significant intraprovincial powers are materially restricted when it comes to export of resources out of province (given federal paramountcy) or out of Canada (given exclusive federal jurisdiction over international trade). Provinces may also regulate pipelines, mines and other facilities via section 92(10), provided, again, that these do not extend beyond provincial boundaries. In the simplest terms, provincial legislative dominance means that provinces, as a general rule, will regulate in their own individual interests. And it stands to obvious reason that a scenario in which each province maximizes its own legislative interests (or, say, welfare) is hardly conducive to the maximization of pan-Canadian or federal interests (or welfare or indeed, ultimately, strategic power). A presumption to the contrary would be a patent fallacy of composition; that is, a false presumption that something that is true of the part is necessarily true of the whole.

Strictly speaking, therefore, such vesting of ownership and legislative power over natural resources with the provinces is antithetical to the idea of ensuring constant (standing) and adequate supply of key natural resources for the country as a whole, and, in purely strategic terms, in the effective, ultimate service of the military and diplomatic instruments in particular. Writes G.V. La Forest (then not yet a Supreme Court judge) in this respect:

The raising of a revenue is not the sole reason that public property is of fundamental importance to the provinces. It also provides them with a powerful instrument for the

\footnotetext{
${ }^{82}$ In addition to section 92A, we note here, among the section 92 heads of power, section 92(13) on property and civil rights, in particular, but also sections 92(5), 92(10) and 92(16).
} 
control of their economic and political destinies. By requiring that resources from public property be processed within its boundaries, a province can materially contribute towards the establishment of secondary industries there, and prevent the export of raw material to other countries [or indeed, per section 92A, to other provinces, provided this prohibition is for all provinces, and provided there is no repugnancy with federal law]. ${ }^{83}$

Having established that, in terms of a national planning function, provincial dominance over natural resources is largely astrategic, if not anti-strategic, let us posit further than in the absence of an emergency, the Canadian constitutional framework does not strictly vest in the federal government the capacity to ensure or require (rather than politically incentivize) that there be continuous and adequate supply of needed natural resources. ${ }^{84}$ (The federal government may, in the event of a longterm dearth of, say, energy resources, acquire legislative and regulatory responsibility for energy imports and offshore exploration, but it must for the most part, notwithstanding the prospect of federal-provincial cooperative agreements, defer to the legislative and regulatory lead of the provinces in most traditional scenarios of energy exploration.)

83 Gérard V. La Forest, supra note 76, pp. xii-xiii. En passant, further to this, an interesting line of enquiry concerns the provincial capacity to erect so-called 'sovereign wealth funds'-effectively, strategic revenue reserves-from their natural resource revenues. As Alberta has proven with its Heritage Savings Trust Fund, there is evidently no constitutional bar to provinces accumulating natural resource royalties (in addition to other possible provincial revenues) for purposes of strategic expenditure in major projects. The federal government may also create sovereign wealth funds for national strategic purposes, but it clearly does not have availed to it the significant royalties from provincial natural resources. It does, however, on top of many other revenue sources, have general access to resource royalties from the territories (except the Yukon) and certain offshore sources (see supra note 81). (See also the related discussion on federal and provincial spending powers below in the section on national economic might.)

${ }^{84}$ Strictly speaking, there is today in Canada no national policy (unlike the old National Energy Policy) for monitoring national energy supply, and for ensuring adequacy of such supply. Supply decisions - often market-driven, including by dint of the international trading dynamics discussed below-are in practice made intraprovincially, both by provincial governments and private suppliers. 
Short of an emergency, therefore, if the federal government, for purposes of ensuring an ongoing minimal national supply of energy in the event of a national shortage (including for the military and diplomatic instruments of the state), wanted to create, say, a national strategic energy (more specifically, a petroleum) reserve, it would likely have to purchase such energy from the provinces and private suppliers at market rates. This means that a national strategic energy reserve is constitutionally possible (through the federal spending power, which we take up later in this piece), but otherwise awkward (and not inexpensive) - thereby making Canada's constitutional framework strategically quite inefficient in respect of ensuring adequacy of natural resources on a national scale. (Provinces, of course, for their part, could legislate with relative ease under section 92A to ensure adequacy of provincial supply, policy-political praxis notwithstanding.)

Having said this, the federal government has at its disposal a number of powerful constitutional and quasi-constitutional tools to be able to mobilize, on an ad hoc and emergency basis, strategic or essential natural resources where these are in short supply, poorly distributed or otherwise needed. The most powerful of these tools is the famous Emergencies Act, which, as stated above, is a function of the federal government's rather sweeping emergency powers under the emergency branch of the POGG power in the 1867 Act. Under each of the four types of national emergency in this Act, there are exceptional provisions-all as yet unlitigated - that empower the government to ensure that scarce supplies and essential resources or services are provided. In a public welfare emergency, for instance, section 8(c) provides for federal requisition, use or disposition of property; section 8(d) provides for the authorization of, or direction to any person, or any person of a class of persons, to render essential services provided there be reasonable compensation for services so rendered; and section 8(e) provides for the regulation of the distribution and availability of essential goods, services and resources. Or in the event of an international emergency, the Act provides at section 30(e) for the same power as in section 8(e), as well as for the control or regulation of any specified industry or service, including the use of equipment, facilities and inventory [section 30(a)], the appropriation, control, forfeiture, use and disposition of property services [section 30(b)], and, more specifically 
to the defence instrument, the authorization and conduct of inquiries in relation to defence contracts or defence proper, or to hoarding, overcharging, black marketing or fraudulent operations in respect of scarce commodities. The Emergencies Act coexists with the predecessor Energy Supplies Emergency Act, also rooted in the federal emergency power, which states at section 15(1), specifically in relation to petroleum resources, that when the "the Governor in Council is of the opinion that a national emergency exists by reason of actual or anticipated shortages of petroleum or disturbances in the petroleum markets that affect or will affect the national security and welfare and the economic stability of Canada, and that it is necessary in the national interest to conserve the supplies of petroleum products within Canada, the Governor in Council may, by order, so declare and by that order authorize the establishment of a program for the mandatory allocation of petroleum products within Canada in accordance with this Act.”

Of course, as established earlier, both the Emergencies Act and the Energy Supplies Emergency Act do not displace the entirety of the royal prerogative of the government in respect of national security or emergencies. Indeed, this prerogative also hovers over the controversial 'proportionality clause' (Article 605) in the North American Free Trade Agreement (NAFTA), which repeats the prohibition in the Canada-U.S. Free Trade Agreement on Canadian restrictions of energy exports to the United States (in the NAFTA case, to Mexico also) for reasons of national conservation, supply shortages and price stabilization provided the share of total energy supply available for export purchase by the U.S. (or Mexico) from Canada falls below the average level of the previous 36 months. ${ }^{85}$ Although as yet unligated, the only apparent legislative exceptions to this clause are found in Article 107 of the NAFTA, which states that energy imports and exports may be restricted for reasons of national security - that is, as defined in the Article, to the extent necessary for Canada to (a) supply a military establishment [...] or enable fulfillment of a critical defence contract; (b) respond to a situation of armed conflict; (c) implement national policies or international agreements relating to the non-proliferation of nuclear weapons or other explosive devices; or (d)

\footnotetext{
${ }^{85}$ Indeed, the Article 605 proportionality clause tracks an almost identical proportionality clause in Article 315 in respect of all goods subject to the NAFTA.
} 
respond to direct threats of disruption in the supply of nuclear materials for defence purposes. If these conditions are not met, Canada could still, in strict constitutional terms, easily defer to the emergency prerogative (or in extremis, the doctrine of state necessity) to assure its domestic supplyeven if this be in breach of the NAFTA, and even if this would doubtless bring about political and strategic retaliation by the U.S. (In practice, Canada would likely far sooner do this or, more readily, legally attempt to justify or litigate its actions as being in accordance with Article 107, than rescind the treaty outright. $)^{86}$ Moreover, as discussed above, if necessary - for instance, in the event of a national energy shortage-, the federal government could arguably use its spending power to purchase exported oil from the provinces on the free market, within the terms of the NAFTA. Of course, this would require the federal government to effectively outbid potential American and Mexican buyers; that is, on volumes of oil over and above those which would have to be made available to them, based on historic sales over a representative period-a high price indeed for imperfect strategic efficiency.

The declaratory power in section 92(10)(c) is also available to the federal government, via legislation, insofar as it may deem certain "local works and undertakings" related to certain natural resources (or indeed, food) to be for the general advantage of Canada. As discussed above, the declaratory power was famously used by the federal government in respect of the uranium mines after the Second World War. Indeed, the constitutional possibility, politically realistic or not, of the declaratory power being used by the federal government, via Parliament, to invoke federal control of oil and natural gas during the 1970s OPEC oil embargo was a key driver for the western provinces in the negotiations leading eventually to the enactment of section 92A, the natural resource amendment, in 1982, even if this section does not, in its final form, at all address the declaratory power. ${ }^{87}$ This would seem to reaffirm a matter

${ }^{86}$ See Stephen McBride. "Quiet Constitutionalism in Canada: The International Political Economy of Domestic Institutional Change" for an interesting discussion of the effectively quasi-constitutional character of NAFTA in Canadian governance [(2003) 36:2 Cdn J. Pol. Sci. 251].

${ }^{87}$ See the discussion of this provincial fear in J. Peter Meekison and Roy J. Romanow, "Western Advocacy and Section 92A of the Constitution" Origins and Meaning of Section 92A (Montreal: Institute for Research on Public Policy, 1985), p. 18. 
that has been intimated at several points over the course of this piece-that is, that the strategic efficacy of a given strategic section in the Constitution may issue not only from the existence of that section, but, in practice, also from the mere threat of its use.

One could perhaps make an ambitious theoretical argument that the declaratory power, unlike the emergency instruments discussed above, could also be levered by the federal government, in its general regulation of a given essential natural resource, to ensure an ongoing or standing country-wide supply of that same essential natural resource, including through legislation relating to intraprovincial exploration and development of the resource in question. One could arguably envision such a scenario in the event that, say, a private company were to refuse or were dilatory in exploiting or distributing energy from a prominent source regulated by a given province. Were that energy seen by the federal government as incontrovertibly critical to adequate national supply, the federal government could threaten or, in the alternative, actually use the declaratory power to assume regulatory control of a given intraprovincial energy sector, which in turn could lead to legislation to compel the company in question to accelerate the exploitation or distribution of energy.

Quaere: In the alternative, could the federal government not purchase, for reasons largely or entirely strategic, some or all of obstructionist private company in question and assert legislative jurisdiction thereover under section 91(1A) of the 1867 Act? Indeed, section 91(1A) states that the federal government has legislative responsibility for its own public debt and property. (Of course, federal executive power over such debt and property would flow from the very fact of federal ownership, as with a private party-rather than from the royal prerogative.) Such a scenario is not meaningfully explored in the constitutional literature, and hardly addressed in the case law-again, perhaps, a measure of the absence of strategic tradition and, a fortiori, strategic thinking in Canadian constitutional culture, even if the considerations are largely counterfactual at this juncture. Were, however, the federal government to purchase a proprietary interest in, say, a private energy concern in order to advance national strategic interests, there would seem to be an uncontroversial prima facie basis for federal laws and regulations (including requirements for specific rates or quanta of energy production) to apply thereto. The 
holding in British Columbia v. Lafarge Canada Inc. affirms that "public property ha[s] to encompass some element of ownership by Canada [the Government of Canada] in order to receive constitutional immunity” from provincial laws (in the Lafarge case, provincial-land use laws) relating to that property. ${ }^{88}$

Indeed, provided the federal law or regulation in question relating to the acquired property legitimately falls, in pith and substance, under a federal head of power [section 91(1A) or other], there is little to suggest, other things being equal, that the federal government would need to buy anything but a minor or even nominal stake in a private company in order to assert legislative jurisdiction thereover. Justice Bastarache implies as much in his concurring judgment in Lafarge, writing at paragraph 123:

[T] he relevant test is whether there is evidence of a sufficient proprietary interest in the lands on the part of the federal Crown. [I]t is clear that Crown ownership of land generally coincides with its prima facie classification as $\mathrm{s}$. 91(1A) public property [...] [E]ven a partial proprietary interest of the federal Crown in land will help establish a sufficient basis for classifying the land as public property under s. 91(1A). ${ }^{89}$

Given the considerable fiscal (revenue-collecting) capacity of the federal government, both in absolute terms and relative to the provincial governments, in the structure of the Canadian federation, this would seem to given the federal government disproportionate strategic opportunityagain, allowing for policy-political considerations - to make, or threaten to make, targeted purchases of private or even provincial property across the country in order to assert federal legislative jurisdiction for strategic purposes. $^{90}$ Having said this, while federal legislative jurisdiction over

${ }^{88}$ British Columbia v. Lafarge Canada Inc., [2007] S.C.J. No. 23.

${ }^{89}$ Professor (and later Supreme Court Justice) Gérard La Forest (supra note 79 at pp. 134-135) put it thus: 'In a word, the term "property" in section 91(1A) is used in its broadest sense and includes every kind of asset and partial interest.'

${ }^{90}$ Recall that the federal spending power, discussed at some length below in the section on economic might, is also in part a function of section 91(1A). The other most relevant 
such property could be somewhat inured from relevant provincial laws of general application by virtue of the doctrine of interjurisdictional immunity, ${ }^{91}$ it would be unconstitutional for the federal government to acquire a proprietary interest in a given concern, only to proceed to legislate (colourably), in pith and substance, in an area of provincial competence-indeed, such as natural resources, grosso modo, under section 92A. However, if the said legislation does indeed relate in pitch and substance to a federal proprietary interest, and if there be a coinciding provincial proprietary interest (with or without the existence of private proprietary interests), then federal legislation, through the doctrine of federal paramountcy, would naturally trump provincial legislation in respect of that property.

Evidently, the declaratory power, discussed amply above, could also be used by the federal government to accomplish-perhaps less 'elegantly,' in strategic terms - that which could otherwise be done by acquiring a proprietary interest in a concern of national strategic interest. And, to be sure, if pressed, the federal government has non-negligible expropriation powers. The federal government may expropriate, for all intents and purposes, only to achieve ends falling within its legislative jurisdiction. So in respect of an obstructionist, unproductive or incompetent private concern providing critical services to, say, the defence industry, it would seem to follow that the federal government, for legislative purposes falling under the federal militia power in section 91(7) of the 1867 Act, could legitimately expropriate the concern. (This would in fact suggest that the federal government has greater war-planning economic capabilities,

head of power for the federal spending power is section 91(3). Interestingly, Justice Bastarache, again in Lafarge, supra note 88, waxes somewhat 'strategically' —again, at paragraph 123, noting that "a focus on the federal Crown's proprietary interests is consistent with the historical origins and development of federal jurisdiction over public property as a way to ensure that the federal Crown would possess and be the proprietor of sufficient resources to establish and maintain a transcontinental economy in the early years of Confederation.”

91 The majority in Lafarge, supra note 88, at paragraph 55, stated: "While federal ownership of land does not create an enclave from which all provincial laws are excluded, provincial law cannot affect the exercise of a 'vital part' of federal property rights." 
constitutionally speaking, than meet the eye through a mere survey of relevant 'quasi-constitutional' statutes under the militia power. We touch on some of these statutes below in the section on the economy.) Wrote Gérard La Forest:

The power of expropriation of privately owned lands would appear to be inherent in most heads of power under section 91 of the [1867] Act, ${ }^{92}$ as well as expropriation consequent upon a declaration of a work to be for the general advantage of Canada under section 92(10)(c) of that Act. This might possibly include power to expropriate land by virtue of section 91(1A) for the more convenient use of public property, but this would be narrowly construed; the head could not be used as a colourable device for appropriating land for purposes falling outside Dominion legislative power. The federal power of expropriation is by no means limited to purposes coming under enumerated heads of power; expropriation by virtue of the general power to legislate concerning peace, order and good government is also valid. [...] Finally, there seems no constitutional impediment to the federal parliament expropriating private property without compensation, however undesirable this may be [in practice]. ${ }^{93}$

The federal government would also be well within its constitutional rights, in extremis, to expropriate provincial lands without compensation in order to execute purposes falling squarely under a federal head of legislative power; for instance, the building of interprovincial or international pipelines, railways or bridges-all key to effective

92 See Reference re Waters and Water-Powers, [1929] S.C.R. 200.

${ }^{93}$ Gérard La Forest, supra note 79 at pp. 149-150. Having said, however, that there is no strict constitutional bar to federal (or indeed provincial) expropriation of private property without compensation, Anglo-Canadian statutory interpretation does require such compensation for the private owner in the absence of explicit language absolving the expropriating government of such an obligation [Hogg, supra note 75 at p. 29-9 (looseleaf)]. 
mobilization of natural resources for strategic purposes. It stands to reason, therefore, that these federal expropriation powers-even in times short of emergency-would increase materially to the extent that there is jurisprudential expansion of strategic federal powers like POGG (in particular, the said national concern branch, or even a fourth branch dealing with matters of interprovincial significance, supra note 62) and trade and commerce (discussed at length below).

The other dimension of supply is the actual physical security of the natural resource in question (or indeed, parenthetically, of agriculture and foodstuffs), as well as that of the infrastructure-so-called national critical infrastructure-supporting its production and distribution. The declaratory power and the section 91 general power (POGG, under the national concern branch), affirmed in the aforementioned Ontario Hydro case $^{94}$, were primarily concerned with such physical security in the Canadian nuclear sector. (Ontario Hydro is arguably the only decision of any strategic import involving section 92A since its very inception in 1982.) In that decision, Justice La Forest wrote for the majority at paragraph 83 that he "cannot believe that [section 92A] was meant to interfere with the paramount power vested in Parliament by virtue of the declaratory power (or for that matter Parliament's general power to legislate for the peace, order and good government of Canada) over [a]ll works and undertakings constructed for the production, use and application of atomic energy." It follows, therefore, that in respect of critical infrastructure like pipelines, electric generating facilities or grids, as well as certain transport modes, even if these have an intraprovincial character, the federal government, if it so wishes, has at least one 'in' through the declaratory power for regulating the security of these assetswhere these are deemed of national strategic value. Of course, interprovincial critical infrastructure, such as certain pipelines (under the National Energy Board Act) and railways (which we discuss below in the section on the economy), is already regulated by the federal government for safety and security. ${ }^{95}$

\footnotetext{
${ }^{94}$ Supra note 64.

${ }^{95}$ We do not attempt to address directly here the very practical (and manifestly complex) issues relating to the fact that, as in most Western countries, the vast majority of
} 
Can the federal government restrict export of essential, needed or otherwise valued natural resources to other countries or groups of countries whose behaviour it seeks to influence? Alternatively, can the federal government use Canadian natural resource exports or imports (or indeed food) as a diplomatic tool to incentivize or reward another country or group of countries? (In diplomatic terms, as mentioned above, such transactions are often considered part and parcel of so-called 'linkage' strategies, whereby country A links or attaches certain benefits or punishments for country B in a given policy area $x$-in the event, natural resources - to the state of the A-B relationship in policy area $y$-say, in military affairs.) Both courses of action would on their face seem uncontroversial under the Canadian Constitution. The royal prerogative in combination with the POGG residual branch and the trade and commerce power [section 91(2)] as legislative heads of power, give the federal government all the constitutional authority it needs to play such diplomatic 'hard ball,' as it were, should it so wish. (Of course, as discussed above, the constitutional capacity should be seen in light of the associated federal constitutional incapacity to easily assure constant adequate domestic supply of key natural resources in non-emergency situations.) In practice, the Special Economic Measures Act and the Export and Import Permits Act, both discussed above, provide the legislative backing for such action. $^{96}$ Of course, while constitutionally permissible, such action is

Canadian critical infrastructure (even as it relates to natural resources) belongs to the private sector. This is a policy matter (or indeed choice), and not, strictly speaking, a constitutional one.

${ }^{96}$ Section 21(1) of the Investment Canada Act provides for the Minister of Industry to bar certain purchases of Canadian assets by foreign interests if he or she deems this purchase to not be of "net benefit" to Canada. The criteria informing "net benefit" are broadeven sufficiently broad, one could argue, as to make the often sought addition of 'national security' grounds for exclusion of foreign purchasers redundant (see the May 2008 blocking by the Minister purchase of the Information Systems Business of Macdonald, Dettwiler and Associates Ltd. (DTA) by the American aerospace and defence concern ATK, presumably on security grounds). This statute could evidently be used to strategically block foreign ownership of certain strategic natural resources (including energy resources), and could be have the attendant effect of blocking exports of (or in effect 'domesticating') that resource, depending on the nature of the ultimate owner of the resource. 
invariably subject to the various restrictions of relevant trade deals and frameworks. In the NAFTA, for instance, Article 103(1) stipulates that, subject to certain exceptions (not relevant for our purposes), there are to be no restrictions on imports or exports of goods between the three contracting countries. And yet, Article 103(3) stipulates, in almost the same breath, that should the aforementioned import or export restrictions be adopted by a given country, reprisals in the form of countervailing restrictions are permitted. All of this, naturally, speaks to the plain fact that, on top of it being constitutionally undisputed, the policy option of restricting natural resource exports or imports within the NAFTA context (and certainly outside of it), while practically available to Canada, would evidently come with costs. (Over and above countervailing duties, to the extent that Canadian diplomatic 'linkage' is applied to a strategically more powerful or capable trading partner, such as the United States or the European Union, one could presume that such costs could often prove prohibitive to the imposition of such restrictions. Against a strategically less powerful or capable partner, such as, say Mexico, however, such costs could, in certain circumstances, very well be outweighed by the presumptive benefits of the strategic imposition of restrictions by Canada.)

Finally, natural resources, and perhaps energy resources in particular, in Canada are unquestionably a highly significant historical driver of the national economy. Indeed, until the 1970s, when many Canadian governments - federal and provincial-began to see high oil prices as a rationale for privileging rent capture as a distinct policy objective, Canada's natural resources were, largely on the basis of the staple theory of economic development, seen as a primary driver of aggregate economic growth (or variants thereof). For our purposes, other things being equal, it stands to reason that the larger the standing economic or industrial might of a country, the greater its aggregate strategic strength. We take up this very theme in the next section.

\section{NATIONAL ECONOMIC MIGHT}

National economic might or capacity is, in the most obvious sense, connected to the military instrument by dint of the national capacity, in both peacetime and war emergencies, for pure military production and 
indeed modernization. By this we refer to military assets like ships (shipbuilding classically being a major economic industry), planes, tanks, vehicles and munitions, inter alia-all expensive goods that are necessarily underpinned by a certain economic mass. (Let us leave aside, for purposes of this paper, the commonly understood multiplier effect of military production on the economy or, in extremis, talk of a strict military-industrial complex.) The federal Defence Production Act, constitutionally authorized by the already discussed federal militia power [section 91(7)], gives the Minister of Public Works and Government Services the presumptive lead on organizing national defence production or supplies required to meet the needs of the Department of National Defence-in short, the military needs of Canada. The Act even suggests at section 12 that "[t]he Minister shall examine into, organize, mobilize and conserve the resources of Canada contributory to, and the sources of supply of, defence supplies and the agencies and facilities available for the supply thereof and for the construction of defence projects and shall explore, estimate and provide for the fulfilment of the needs, present and prospective, of the Government and the community with respect thereto and generally shall take steps to mobilize, conserve and coordinate all economic and industrial facilities in respect of defence supplies and defence projects and the supply or construction thereof." However, because this section, like the rest of the Act, has not been litigated in any strategically meaningful sense, we do not at this time of writing know the precise parameters of the federal government's power to substantially organize or mobilize Canada's defence industry (or indeed its economy at large), at least in peacetime or on a standing basis. In the event of a declared war emergency, of course, the Defence Production Act is supplemented by the Emergencies Act, well treated above, which grants the Canadian federal government, under a declared war emergency, expansive powers of economic mobilization and organization in support of the country's military efforts. (Evidently, the larger the economic capacity of the country, other things being equal, the greater its ability to support the military campaign and related industries and production in the actual event of war, and to deter a potential enemy in the event of threatened war, given that the enemy would to some extent infer the war-fighting capability of the country from its economic mass. In this latter respect, conversely, the smaller a country's economic capacity, other things being equal, the less its capacity to discourage strategic confrontation or, in extremis, military attack by another country.) 
In addition to direct defence production, there is a country's capacity to purchase or import from other countries the assets necessary for war preparation (or deterrence) and war-fighting. The larger the economy, other things being equal, the greater its purchasing power for such assets. That said, it stands to reason that excessive importation of strategic military assets (as with natural resources, discussed above) also poses a significant strategic risk for a country, given its dependence on foreign supply and supply or distribution routes that could be disrupted at critical strategic moments. Still, strictly speaking, we will concede that the balance between indigenous defence-related production and imported production is very much a policy choice, rather than a constitutional concern, and that the core strategic observation stands: the larger the economic capacity of the state, the greater the potency of its military instrument, other things being equal. (Of course, as established in the natural resources section, it is not just the magnitude of the factor of power-in this case, the national economy - that matters for purposes of determining aggregate strategic power, but also, critically, the capacity of the state to mobilize the factor, directly or indirectly, in support of the cardinal strategic instruments - the military and diplomatic instruments.)

The aggregate capacity of the Canadian economy also clearly informs Canada's diplomatic instrument. For instance, a strong economy generally bolsters a country's negotiating position (indeed, its attractiveness to potential partners) in respect of international trade and investment. It increases the national capacity to reward other countries with such diplomatic assets as aid, food, intelligence or information and, as described above, natural resources sold or exported on favourable terms. The capacity to punish-for instance, through economic sanctions or, say, trade or investment diversion to other countries-is similarly commensurate with the strength of the economy. What is more-and this applies equally to the diplomatic and military instruments-, economic capacity speaks to the sheer potential size or magnitude of the national diplomatic and military forces; that is, in terms of total potential effectives and associated funding.

Naturally, the aggregate capacity of the Canadian economy is a function of an extremely complicated cocktail of variables. The same is true of the economy's capacity for strategic mobilization. We cannot 
possibly tease out all these variables in the context of this piece, but we will attempt to survey some of those which presumptively provide the essential economic backbone of Canadian strategic power. These include: the macroeconomic capacity to resist strategic shocks; the general strength of the national economic union; the capacity to protect or lever strategic industries or sectors in international trade and investment agreements; and the constitutional character of the national strategic transportation infrastructure.

The federal government uncontroversially controls considerable national macroeconomic instruments. In the event, therefore, of strategic shocks directly related to the economy or bearing economic consequences or manifestations - for instance, a foreign oil embargo à la OPEC 1973, a concerted or unwitting run on the Canadian dollar by foreign parties or an international banking crisis, as exists at this time of writing, or indeed even a proper war-it is the federal government that is the presumptive macroeconomic lead in Canada. In division of power terms, not only has the federal government legislative responsibility for the banks under sections 91(15) [banking, incorporation of banks and the issue of paper money] and 91(16) [savings banks] of the 1867 Act, but, more importantly, it has a constitutional monopoly on monetary policy, writ large, under several sections of the 1867 Act-to wit, section 91(14) on currency and coinage; the said sections 91(15) and 91(16); section 91(18) on bills of exchange and promissory notes; section 91(19) on interest; section 91(20) on legal tender; and perhaps even the federal trade and commerce power in section 91(3), which we take up below. ${ }^{97}$ The Bank of Canada, which evidently did not exist at Confederation, among other

\footnotetext{
${ }^{97}$ Reference re Alberta Legislation, [1938] S.C.J. No. 2. It stands to reason that the large number of heads of legislative power supporting the Bank of Canada Act speaks to the breadth, and indeed, the strategic character of the Bank's operations. The preamble to the Bank of Canada Act states that the Bank is required to "regulate credit and currency in the best interests of the economic life of the nation, to control and protect the external value of the national monetary unit and to mitigate by its influence fluctuations in the general level of production, trade, prices and employment, so far as may be possible within the scope of monetary action, and generally to promote the economic and financial welfare of Canada." One could also submit, given the breadth of these activities, that the Bank of Canada Act could also find a home under the residual or national concern branch of POGG.
} 
things, regulates the national money supply, regulates inflation via the setting of the key interest rate (or key policy rate) and has massive capacity to inject into, or withdraw from, the banking system liquidity in the interest of national economic goals such as price stability, protection or promotion of the national currency and even of aggregate economic product. The Bank operates at arm's length from the federal government, but is still clearly a creature of federal power.

In addition to its instruments of monetary policy, the federal government, as discussed earlier in this piece, enjoys expansive taxation and spending (i.e. fiscal) powers under sections 91(1A) and 91(3) of the 1867 Act, relating respectively to public debt and property and the raising of money by any mode or system of taxation. ${ }^{98}$ Section 91(1A), in particular, allows the federal government to borrow very significant amounts of money-both from Canadian and international sources-in order to drive national economic goals, bearing in mind policy-political considerations. $^{99}$ In other words, over and above monetary policy, the federal government, in the event of a negative strategic shock, is able to lever the far more powerful fiscal policy instrument to stimulate, propel or stabilize the economy_over time, and other things being equal—through

\footnotetext{
98 Other sections likely (arguably) relevant to the constitutional existence of a muscular federal spending power include sections 102 and 106 of the 1867 Act, both dealing with federal appropriations. Section 102 states: "All Duties and Revenues over which the respective Legislatures of Canada, Nova Scotia, and New Brunswick before and at the Union had and have Power of Appropriation, except such Portions thereof as are by this Act reserved to the respective Legislatures of the Provinces, or are raised by them in accordance with the special Powers conferred on them by this Act, shall form One Consolidated Revenue Fund, to be appropriated for the Public Service of Canada in the Manner and subject to the Charges in this Act provided." Section 106 states: "Subject to the several Payments by this Act charged on the Consolidated Revenue Fund of Canada, the same shall be appropriated by the Parliament of Canada for the Public Service.” Of course, for both sections, "Public Service" of Canada is to be understood broadly-that is, something approximating the general welfare of the country (and certainly not as referring the federal civil service proper!).

99 One might presume that section 91(4) of the 1867 Act, referring as it does to the borrowing of money on the public credit, would also be a relevant head of power for federal debt. However, the jurisprudence on this section is paltry, and it would thus seem that section $91(1 \mathrm{~A})$ is the dominant supporting head of power.
} 
deficit spending ${ }^{100}$; or, via section 91(3), to play with tax rates and incentives for the same purpose.

The British historian Niall Ferguson is perfectly direct in his recognition of the strategic import of national debt (fiscal policy) and central banks (monetary policy) over the ages. He posits the evolution, by the eighteenth century, of four peculiar national institutions (a so-called

100 Note the enormous constitutional flexibility of the federal spending power. Hogg, supra note 26 at pp. 174-175, suggests: "[T]he better view of the law is that the federal Parliament may spend or lend its funds to any government or institution or individual it chooses; and that it may attach to any grant or loan any conditions it chooses, including conditions it could not directly legislate. There is a distinction, in my view, between compulsory regulation, which can obviously be accomplished only by legislation enacted within the limits of legislative power, and spending or lending or contracting, which either imposes no obligations on the recipient (as in the case of unconditional grants) or obligations which are voluntarily assumed by the recipient (as in the case of a conditional grant, a loan or a commercial contract). There is no compelling reason to confine spending or lending or contracting within the limits of legislative power, because in those functions the government is not purporting to exercise any peculiarly governmental authority over its objects.” Even Brun and Tremblay, supra note 24 at p. 433, concede as much: «Les provinces et le fédéral peuvent donc faire ce qu’ils veulent de leurs avoirs. Ils peuvent les dépenser dans les domaines de l'autre ordre de gouvernement sans régir ceux-ci législativement. » They add, however, this proviso at p.432 in respect of conditionality attached to the (federal) spending power: 'Il n'en reste pas moins que la décision dans Winterhaven [Winterhaven Stables Ltd. v. Attorney General Canada (1986), A.J. No. 460] laisse croire qu’à partir d'un certain stade, l'imposition de conditions peut changer le caractère véritable d'une législation et la rendre vulnérable. Ainsi, le fédéral était intervenu trop activement dans une matière provinciale lorsqu'il a légiféré sur l'assurance-chômage (avant qu’il ne réussisse à se faire transférer la compétence à cet égard) [Attorney-General Canada v. Attorney-General Ontario, [1937] A.C. 355]. Le fédéral avait plaidé que par son pouvoir de taxer, il pouvait constituer un fonds, et que par son pouvoir relatif à la propriété fédérale, il pouvait ensuite en disposer à sa guise. Mais le Conseil privé jugea la loi invalide parce qu'en réalité elle réglementait ce secteur de la vie sociale. Dans un jugement plus récent, le juge Pigeon, au nom d'une majorité de juges de la Cour suprême, a exprimé l’opinion suivante: «...l'intrusion fédérale dans le commerce local est tout aussi inconstitutionnelle lorsqu'elle se fait par des achats et des ventes que lorsqu'elle se fait d'une autre manière. » [Reference re Agricultural Products Marketing Act, [1978] 2 S.C.R. 1198] Cette affirmation laisse voir que le simple droit d'agir (en achetant, en vendant ou en dépensant, par exemple) peut devenir vulnérable s'il fait partie d'une intervention qui se veut régulatrice. Divers dicta dans l'affaire Dunbar [Dunbar v. Attorney-General Saskatchewan (1984), 11 D.L.R. (4th) 374] accréditent aussi cette approche.' 
"square of power") designed for the financing of wars by states. The first two are a national parliament and a tax-gathering bureaucracy. He goes on to write:

Third, a system of national debt allowed a state to anticipate tax revenues in the event of a sudden increase in expenditure, such as that caused by a war [or, indeed, some other strategic event, shock or crisis]. The benefit of borrowing was that it allowed the costs of wars to be spread over time, thus 'smoothing' the necessary taxation. Finally, a central bank was required not only to manage debt issuance but also to exact seigniorage of paper money, which the bank monopolized. ${ }^{101}$

One of the great and interesting strategic complications with the federal fiscal instrument, however, is that-constitutional division of powers oblige - the provincial governments also have a constitutional capacity to borrow $^{102}$-from intraprovincial sources, national and international sources - on top of their own quite expansive spending powers based on section 92(5) [the management and sale of the public lands belonging to the province and of the timber and wood thereon], the historically important property and civil rights power in section 92(13), as well as on section 92(2), which relates to direct intraprovincial taxation for the raising of revenue "for provincial purposes."103 Note that the turn of phrase "for provincial purposes" has, for all intents and purposes, become constitutionally nugatory; that is, according to Hogg, quoting Chief Justice Duff in the Unemployment Insurance Reference ${ }^{104}$, it means only that

${ }^{101}$ Niall Ferguson, The Cash Nexus: Money and Power in the Modern World, 1700-2000 (New York: Basic Books, 2001), p. 15.

102 The provincial borrowing power is arguably rooted in section 92(3) of the 1867 Act, which relates to the borrowing of money on the sole credit of the province.

${ }^{103}$ We might also add, in support of the provincial spending power, sections 109 and 117 of the 1867 Act, both discussed previously in this paper.

${ }^{104}$ Attorney-General of Canada v. Attorney-General of Ontario, [1936] S.C.R. 427. The subsequent appeal to the Privy Council, while dismissed on the facts of the case, resulted in dicta that famously defended the federal spending power-to wit: "That the Dominion 
'revenue is raised "for the exclusive disposition of the legislature.",105 Hogg also notes the following:

In fact, the provinces have never recognized any limits on their spending power and have often spent money for purposes outside their legislative competence, for example, by running a commuter train service on interprovincial trackage, by acquiring an airline, by giving international aid, or by paying casino profits to Indian communities. ${ }^{106}$

This effectively means that, while the federal spending power is constitutionally very expansive (in theory limited, other things being equal, only to how much money the federal government can raise), and is nowhere necessarily displaced by provincial spending power (itself also, in theory, a function of the provincial capacity to raise money), its potency, in strategic terms - that is, in advancing national strategic endsmay be notably mitigated or obstructed should one or more provinces use their spending power for ends incommensurable or indeed at direct crosspurposes with such national strategic ends. (Unlike with legislative powers, there is no doctrine of federal paramountcy in respect of spending powers-hence our peculiar interest in the matter.) Conversely, the federal spending power could be buttressed or magnified in the event that provincial spending powers are used in strategic alignment with the federal power-that is, for strategic purposes consistent therewith. Indeed, if one carefully examines, in structural terms, the federal political drama unfolding at this time of writing in Ottawa-where the Conservative government, but for prorogation of Parliament, would have faced an apparently unwinnable vote of confidence on a December 2008

may impose taxation for the purpose of creating a fund for special purposes, and may apply that fund for making contributions in the public interest to individuals, corporations or public authorities, could not as a general proposition be denied." [Attorney-General of Canada v. Attorney-General of Ontario, [1937] A.C. 355]. (Hogg supra note 26 at pp. 366-367)

${ }^{105}$ Hogg, supra note 26 at p. 177. See affirmation of the same in Brun and Tremblay, supra note 24.

${ }^{106}$ Hogg, supra note 26 at pp. 177-178. 
[VOL. 05 No. 01

fiscal update or economic statement that seemed exceedingly meek in using the federal fiscal instrument to stimulate a recessionary economy-, it could well be submitted that the federal government was in fact waiting to coordinate its fiscal stimulus package with those portended by the provinces; hence its apparently dilatory action. This line of reasoning would be strongly supported by the fact that, prior to the release of the stimulatory budget at the end of January 2009, an important first ministers' meeting or conference was convened between Prime Minister and premiers to discuss the economy and to coordinate fiscal policy. Such fiscal coordination, of course, were strategic considerations at the fore of the policy agenda, would be influential in determining the extent to which Canada's economic and other factors of power could be mobilized in aid of the state's principal strategic instruments.

Having said all of the above, the critical economic mass or motor which drives the country, and indeed informs federal spending or fiscal capacity, including in respect of the military and diplomatic instruments, consists largely in the Canadian economic union. As such, having largely treated the federal government's direct macroeconomic tools, it is most apposite, strategically speaking, to determine the microeconomic capacity of the federal government in respect of this union. (This capacity relates directly to the overall magnitude of the economy as a factor of power.) In particular, we refer here to its capacity to directly influence the 'tightness' or cohesion of the said Canadian economic union (a microeconomic concern) with the indirect objective, naturally, of maximizing its national growth or total product or output (a macroeconomic concern).

In respect of the domestic economic union, Michael Trebilcock has suggested that it is quite 'tight' or cohesive already, writing the following:

Canadians share a common currency, a closely harmonized tax system, a developed rail and highway transportation infrastructure, and all provincial governments are constrained by section 121 of the Constitution Act [1867], which guarantees that all goods must be permitted to move within Canada without being made subject to provincial tariffs. Since the addition of the Charter [...] in 1982, Canadians have also benefited from section 6, which guarantees personal mobility rights and the right to pursue a 
livelihood in any province of Canada. Furthermore [...], Canadians have also benefited from relatively unhindered capital flows and freedom of investment within Canada. ${ }^{107}$

Indeed, several studies have suggested that the welfare gain to be had from perfect economic union in Canada - that is, one denuded of internal economic barriers - would be in the realm of one to one and a half percent. ${ }^{108}$ (This would presumably include the much vaunted creation of a national securities commission, or the elimination of barriers thereto.) On a static model, this would seem to suggest the maximum magnitude of possible improvement of Canadian economic capacity in the event that the federal government had the requisite constitutional capacity to remove all such barriers. However, on a dynamic model, where the economic factor of power is mixed with other factors of power, such as natural resources or population (or even the 'pure executive,' diplomatic and military factors), this maximum could substantially increase, as would its potential impact on overall Canadian strategic capacity.

As mentioned early on in this piece, the federal trade and commerce power in section 91(2) of the 1867 Act—prima facie the key constitutional head of power for direct microeconomic intervention or indeed legislationled planning - has been largely confined to international and interprovincial trade by dint of restrictive jurisprudence initiated by the Judicial Committee of the Privy Council. (Contrast this with the expansive interpretation given by the courts in Australia to the so-called corporations power in section 51(xx) of the Commonwealth of Australia Constitution Act, 1900 and the commerce clause in Article 1, section 8 of the U.S. Constitution, both of which have greatly facilitated the erection of

107 Michael J. Trebilcock, “The Supreme Court and Strengthening the Conditions for Effective Competition in the Canadian Economy” (2001) 80 Can. Bar Rev. 542 at pp. 550-551. We should stress that Trebilcock refers to the economic union in terms of economic efficiency. Such internal efficiency is not inconsistent with the notion that there are a number of 'north-south' or Canada-U.S. trading corridors for which bilateral trade volumes are in actuality greater than interprovincial trade volumes. See Thomas Courchene, "Federalism and the New Economic Order: A Citizen and Process Perspective” (Montreal: Institute for Research on Public Policy, 2002), pp. 7-8.

${ }^{108}$ Ibid., p. 553. 
[VOL. 05 No. 01

a more cohesive economic union within each federation.) Exclusive federal jurisdiction over international and interprovincial trade is the soidisant first branch of the trade and commerce power, conditioned by expansive jurisprudence by the Privy Council in respect of the provincial property and civil rights power in section 92(13) of the 1867 Act; that is, in respect of most intraprovincial microeconomic transactions. ${ }^{109}$ The soidisant second branch of the trade and commerce power, relating to the federal capacity to regulate general trade for the entire country, was revived by the Supreme Court of Canada in the 1989 General Motors v. City National Leasing case, in which Justice Dickson established a fivepart test for determining whether Parliament had constitutional authority for regulation of general trade. ${ }^{110}$ That holding has reignited speculation that the federal general trade regulatory power will be strengthened over time, in particular as the Canadian economic union and global economic dynamics become ever complex. (We discuss the international trade dimension of this speculation below.) What is more, the logic of the Dickson test is, in at least its fourth and fifth parts, distinctly similar to the logic underpinning the national concern branch of the POGG power (well treated above), which is also generally considered to be of potentially expansive consequence for federal constitutional jurisdiction. As Monahan suggests, "the crucial question in applying the fourth and fifth criteria under the general regulation of trade test is the need to ensure that Parliament is able to respond effectively to national economic

\footnotetext{
${ }^{109}$ The nomenclature for the first and second branches of the trade and commerce power come from the 1881 Privy Council decision in Citizens' Insurance v. Parsons, [1881] 7 A.C. 96. See supra note 23 for discussion of this case and the 'grammatical' genesis of the Privy Council's expansive treatment of the provincial property and civil rights power.

${ }^{110}$ General Motors of Canada Ltd. v. City National Leasing, [1989] 1 S.C.R. 641. The five parts of the test are to be seen as a general guide for constitutionally valid legislation, rather than a pedantic check-list of required criteria. These five parts state that constitutional validity exists if: the impugned legislation is part of a regulatory scheme; the scheme is administered and overseen by a regulatory agency; the legislation is concerned with trade in the country as a whole, rather than trade in a particular industry; the legislation is of such a nature that the provinces jointly or severally would be constitutionally incapable of enacting it; and failure to include one or more provinces in the legislative scheme would jeopardize the successful operation of that scheme.
} 
problems."111 (emphasis added) One might also offer that the possible, embryonic fourth branch of the POGG power-that of matters of interprovincial significance-could be at play here, over time, in strengthening, through jurisprudential channels, federal powers over the national economic union. ${ }^{112}$

Doubtless an effective economic union requires not only centralized legislative capacity to remove barriers to economic flows, but also direct and meaningful circumscription of provincial capacity to erect barriers or blocks to such economic flows. And on this front, section 121 of the 1867, which reads that "All Articles of the Growth, Produce, or Manufacture of any one of the Provinces Shall, from and after the Union, be admitted free into each of the other Provinces," having been interpreted by the courts in the narrow sense of prohibitions on strict interprovincial customs duties, has proved remarkably inadequate in removing barriers to internal trade. ${ }^{113}$ In other words, section 121 has proved an insufficient bar to provincial laws and regulations that are deliberately or inadvertently inconsistent with a maximally efficient national economic union. ${ }^{114}$ On

${ }^{111}$ Monahan, supra note 13, p. 296. It may also be noted that the potential (eventual?) expansive force of the federal trade and commerce power is slowly trickling its way into policy-political praxis. Note the interesting undertaking (or, in strategic terms, the possible threat) of the federal Conservative Party in their 2008 general election platform: "A re-elected Conservative government led by Stephen Harper will work to eliminate barriers that restrict or impair trade, investment or labour mobility between provinces and territories by 2010. In 2007, the government announced that it was prepared to use the federal trade and commerce power to strengthen the Canadian economic union. [...] We [...] are prepared to intervene by exercising federal authority if barriers to trade, investment and mobility remain by 2010." (emphasis added) [Conservative Party of Canada, The True North Strong and Free: Stephen Harper's Plan for Canadians, (Ottawa, 2008), p. 16]

112 Ibid, pp. 271-276.

113 The holding in Gold Seal Ltd. v. Dominican Express Company, [1922] 62 S.C.R. 424 has proved to have distinctive staying power in this regard.

${ }^{114}$ Of course, policy plays hugely here as well, and policy-political context is immensely germane to the choices made by governments. Notes Courchene, supra note 107 at p. 12 on this matter: "[What] is increasingly the essence of nation building are [sic] citizenbased issues as they relate to information empowerment, human capital development, and 
[VOL. 05 No. 01

top of this, the jurisprudence on what has been called 'negative [economic] integration,' which is the removal of such barriers to the economic union, has been less than definitive in denuding the union of barriers to maximal efficiency. ${ }^{115}$ We discuss section 6 Charter mobility rights in the next and final section on population.

On top of the cohesion or force of the strict domestic economic union, the economic capacity of Canada is doubtless also a function of its capacity to effectively (dare we say, muscularly) negotiate international trade and investment agreements that serve to buttress national strategic power, including by increasing the magnitude (or 'mobilizability,' as it

redressing the actual and potential income-distributional fallout from the new global order. The challenge for some federal systems, and certainly the Canadian federation, is that many of these citizenship issues fall under provincial jurisdiction. In some areas, Ottawa (more generally, central or federal governments) can mount a reasonable case on policy, if not on constitutional grounds, for becoming more involved in some of these areas. For example, with knowledge on the cutting edge of competitiveness, Ottawa will be a meaningful player in human capital development no matter what the [C]onstitution says since the country's competitiveness is at stake. In many other areas, however, federal systems are likely headed for considerable jurisdiction[al] in-fighting as central governments are going to be driven in the direction of catering to the citizen-related issues, traditionally the domain of sub-national governments."

${ }^{115}$ Monahan, supra note 13, at pp. 307-310 is fairly optimistic in his interpretation of the holdings in two cases in particular, Morguard and Hunt, in respect of the potential efficiency of the economic union, pending further litigation. He asserts that these holdings suggest that the source of legislation to enhance the proper functioning of the economic union is "the entire framework and structure of the Canadian constitutional order" (p. 307). (This would seem consistent with the thrust of this paper-to wit, that the framework and structure of the Canadian Constitution are pregnant with immense strategic possibilities, in practice, for the Canadian state.) He suggests that this provides justification for federal legislation to create a national securities commission, legislation to prevent the establishment or maintenance of restrictions on free interprovincial movement of persons, goods, services or investments, as well as legislation to provide to create a common set of rules for mutual recognition of standards and regulations by provinces. Trebilcock, supra note 107, for his part, seems less optimistic about the net verdict emerging from the accumulated jurisprudence to date on negative integration. He notes at p. 571 that the Supreme Court's "negative integration case-law seems much more equivocal, contradictory, and less well-developed than the counter-part body of U.S. Supreme Court Dormant Commerce Clause jurisprudence [...] or for that matter [than] the National Treatment jurisprudence developed under the GATT/WTO.” 
were) of the economic factor of power. And, indeed, a pivotal aspect of this negotiating capacity consists in the capacity of the federal government to protect or lever so-called 'strategic sectors'-evidently, in aid of national aggregate power.

Of course, as mentioned above, in Canada, negotiation of international commercial agreements is, strictly speaking, a federal responsibility, but implementation, as discussed above, grâce à Labour Conventions, is divided among the federal and provincial levels of government insofar as the agreement in question deals with questions that fall into both their respective jurisdictions. And, as established, this in practice compromises not only the total Canadian capacity for meaningful implementation of complex, cross-jurisdictional 'deliverables' emanating from international agreements, but often, just as signally, the capacity of the federal government to effectively or decisively assume certain negotiating positions, given the prospective uncertainty or controversy relating to implementation at provincial levels.

While we observed above that international treaties and agreements were a diminishing dimension of modern diplomacy (and indeed strategy), it stands to reason that these same agreements continue to have material impacts on the economic factor of power, and that, as such, the strategic stakes of proper negotiating capacity for the state are not inconsiderable. Of interest, for purposes of our analysis, therefore, is the existence of a growing body of scholarship ${ }^{116}$ suggesting that the Supreme Court, building on a stream of dicta in a number of cases, and also taking heed of the changing international economic environment, could well see it fit to qualify or substantially soften (although likely not outright reverse) the

116 See Trebilcock, supra note 107; also Robert Howse, “The Labour Conventions Doctrine in an Era of Global Interdependence: Rethinking the Constitutional Dimensions of Canada’s External Economic Relations” (1990) 16 Can. Bus. L.J. 171; and finally H. Scott Fairley, supra note 20, as well as in "External affairs in the Constitution of Canada" (1987) 16 Can. Council Int. L. 220. Note, however, that French Canadian scholarship, including by Brun and Tremblay, supra note 24, remains highly laudatory of Labour Conventions, and would doubtless prove highly critical of any reversal of this holding. Hogg, supra note 26 at p. 505, is notably agnostic in respect of such an eventuality in his assessment of the evolution of jurisprudence on the second branch of the federal trade and commerce power. 
[VoL. 05 No. 01

categorical bifurcation of treaty implementation powers from Labour Conventions. Such a qualification or softening, on this line of argument, would be rooted in either the national concern branch of the POGG power or the said second (or general trade) branch of the trade and commerce power in section 91(2) of the 1867 Act. Notes Stephen McBride in this respect: "Trade agreements are now based on deep integration, are no longer confined to goods and are inextricably linked to investment. In these circumstances, the reach of the federal Trade and Commerce power might be interpreted as a much more substantial foundation for federal jurisdiction than formerly."117

Whether such a retreat will actually happen at the Supreme Court is not at all evident. An outright reversal of Labour Conventions seems highly improbable in the foreseeable future, given the long-standing incumbency of this decision and the anticipated political implications, particularly in Quebec, of such a drastic shift in the jurisprudence. ${ }^{118}$ Still, were there anything approaching such a shift, particularly given growing international competition for trade and investment advantage, and in spite of the diminishing import of international treaties in foreign affairs proper, this would be a non-negligible fillip to Canadian economic (and ultimately strategic) capacity.

Of particular strategic relevance in respect of international trade and investment, as mentioned above, is the historically important capacity of the federal government to protect or lever for Canadian strategic advantage or interest (that is, in the service of one or more of the factors of power, or directly in the service of one or both of the diplomatic and military instruments of power) key 'strategic' industries or sectors of the Canadian economy. Due to the potential number of such strategic industries or sectors, it would be impossible to give this aspect of Canadian strategic capacity a proper treatment in this paper, although we have elsewhere effectively done so in respect of natural resources (in particular, Canadian energy resources) and, by limited proxy, food. Other

${ }^{117}$ Supra note 86, p. 261.

118 See supra note 24 about anticipatory political considerations in Privy Council and Supreme Court decision-making. 
strategic sectors that would need to be constitutionally canvassed in order to make a determination of aggregate federal strategic capacity in this regard could include the finance sector, communications, certain manufacturing sub-sectors and indeed transportation-to which we now turn, albeit not with a view to examining international trade and investment dimensions of the national transportation infrastructure.

We might propose that transportation infrastructure, of the various species of infrastructure, has been singularly salient in Canada's economic narrative. (Just as saliently, transportation infrastructure is an aspect of Canada's economy that can manifestly be mobilized in direct support of at least one of the two key strategic instruments of Canadian power-that is, the military instrument. ${ }^{119}$ ) Canadian strategic transportation infrastructure, despite the relative constitutional weakness of Canada's economic union, is largely regulated by the federal government. (As a strict policy matter, much of this infrastructure, across the various transport modes, as with certain critical infrastructure discussed in the natural resources section above, is owned by the private sector.) Railways, historically and indeed presently still strategically critical to Canadian power (especially in relation to the economy and the military instrument), are principally regulated by the federal government. This regulation exists primarily on the strength of section 92(10)(a) of the 1867 Act, which places under federal jurisdiction (or, more precisely, exempts from provincial jurisdiction) lines of steam or other ships, railways, canals, telegraphs, and other works and undertakings connecting a province with any other province, or extending beyond the limits of a province, including internationally. (Notably, the interpretation by the courts of 'works and undertakings' has as a rule been very expansivethat is, taken to include both physical and organizational elements, and taken to be undivided in jurisdictional scope-that is, with federal jurisdiction over interprovincial works or undertakings extending even to local aspects of the work or undertaking in question.) As for noninterprovincial or local railways, as discussed previously, these have often

119 Note the direct military import accorded railways in section 51(xxxvii) of the Commonwealth of Australia Constitution Act, which states that the Commonwealth has legislative power over "the control of railways with respect to transport for the naval and military purposes of the Commonwealth.” 
been declared by the federal Parliament to be for the general advantage of Canada, and as such have been transferred from provincial to federal jurisdiction. (This is to say nothing of the broad federal expropriation powers outlined in our section on executive potency, as well as the federal executive expropriation power for military purposes in section 117.) Interprovincial and international shipping also falls under federal jurisdiction under sections 92(10)(b) and 91(10). [By comparison, the trade and commerce power in section 92(2), because it has historically been interpreted so narrowly by the courts, has had little direct impact on the rail sector, or any of the other transport modes in Canada, for that matter.]

The other 'heavy-lift' transport mode is air travel. Like the rail mode, its regulation is dominated by the federal government under the Canada Transportation Act (exclusive federal responsibility for air services in Canada) and the Aeronautics Act (exclusive federal responsibility for safety and security of passengers, aircraft and airports). The Supreme Court famously determined that aeronautics was an indubitable national concern under the federal POGG power in the 1952 Johannesson $v$. West St. Paul case ${ }^{120}$, noting "the rapid growth of passenger and freight traffic by air, the use of aircraft for the carriage of mails especially to the more remote northern parts of the country, and the necessity for the development of air services to be controlled by a national government responsive to the needs of the nation as a whole" 121

\section{POPUlation}

As discussed above, the exclusive constitutional capacitation of the provinces in section 93 of the 1867 Act to legislate in respect of education is a patent strategic weakness in the Canadian federation, other things being equal (that is, in spite of, say, the cultural benefits of localized public education) - in particular in respect of developing the 'talent' pool

\footnotetext{
120 Johannesson v. West St. Paul, [1952] 1 S.C.R. 292.

${ }^{121}$ Hogg, supra note 26, p. 441.
} 
necessary to populate and animate the state's diplomatic and military instruments. This weakness exists notwithstanding the considerable federal spending power in respect of education and 'human capital' training or formation, a theme typically falling, in legislative terms, under the broad provincial property and civil rights power in section 92(13). ${ }^{122}$ The power to directly tailor curricula to meet national objectivesstrategic and otherwise-is clearly an advantage from which only unitary countries like New Zealand and the United Kingdom can profit, and which, in strategic terms, are the envy of complex federations like Canada. ${ }^{123}$

For purposes of economy, however, we have decided not to belabour in this paper the idea of education as a material contributor to the population element or factor of power. This decision is best explained by the proposition that, assuming a generally high level of country-wide education (as exists and will arguably always exist in Canada), the greater strategic advantage in 'population' terms come from sheer numbers, or sheer, manageable numbers. In short, a better or more 'strategically' educated population of 33 million (Canada's present population) is of

${ }^{122}$ Of course, in practical terms, this spending power has been curtailed by the last several federal governments, both by dint of federal-provincial agreements and federal restraint (although such restraint has been well short of meeting the standard of constitutional convention). Indeed, the last Harper government flirted with the idea of passing a proper statute constricting the use of the federal spending power. (Of course, such a statute, were it ever enacted, would still be sub-constitutional-at least for a while, on our conception of the Constitution - and would still be trumped by sections 91(1A) and 91(3), inter alia, and jurisprudence supporting the constitutional legitimacy of the federal spending power. See, notably, Attorney-General of Canada v. Attorney-General of Ontario, [1937] A.C. 355.)

${ }^{123}$ Consider the question of languages and Canadian strategic leadership in the Americas region - an aspiration articulated by the last Harper government. Whence the critical mass of Spanish or Portuguese speakers so clearly necessary-particularly in the diplomatic and military arms of the federal government-for successful advancement of such an aspiration? Absent a major, sustained push by the federal government via its spending power or via federal-provincial coordination, the federal government must rely largely on the otherwise independent educational regimes of the various provinces - and the independent policy-political choices of their various governments-to generate, over a sustained period, a sufficient number of individuals with the appropriate linguistic training. 
substantially less strategic benefit to Canada than a population of, say, 60 or 70 million people educated at today's standards (even if the pedagogy be 'astrategic' or largely controlled by the provinces). To put it crudely, at 60 million people, Canada would have the demographic mass of today's France or Great Britain, but with greater geography and natural resources. Writes John Mearsheimer:

[T] he size of a state's population and its wealth are the two most important components for generating military might. Population size matters a lot, because great powers require big armies, which can be raised only in countries with large populations. States with small populations cannot be great powers. [...] Population size also has important economic consequences, because only large populations can produce great wealth, the other building block of military power. ${ }^{124}$

More exotically, though, for our purposes, if Canada could also properly or effectively distribute such a greater population across its land mass (that is, in accordance with national strategic objectives-say, in respect of creating more and bigger cities and economic centres, or with respect to the assertion of sovereignty in the North), the strategic impact would be all the greater: the economy would be larger (not least given the economic synergies created by big cities), natural resources more potently exploited, and the diplomatic force and army larger, since the pool of talent from which to draw the effectives to populate these instruments would, of course, be far larger.

Granted, immigration aside, the federal government has certain key constitutional tools at its disposal to attempt to increase the national population [namely the tax and spending power in sections 91(1A) and 91(3), inter alia, of the 1867 Act]-say, to create reproductive tax incentives or baby bonuses to increase the indigenous birth rate. At the same time, however, many equally critical constitutional powers (microeconomic, education, health care) relevant to family planning are at the provincial level. In addition to, or in place of incentivizing an

${ }^{124}$ John J. Mearsheimer, The Tragedy of Great Power Politics (New York: W.W. Norton \& Co., 2003), pp. 60-61. 
increased national birth rate, the other essential constitutional power for increasing national population is that of immigration. And immigration, as mentioned earlier in this piece, is a joint federal-provincial power under section 95 of the 1867 Act, with federal paramountcy. ${ }^{125}$

The federal government sets national immigration targets annually under the Immigration and Refugee Protection Act. It is required by the Act to consult with provinces in setting these national targets, but the Act notes clearly that one its many (indeed, often contradictory) goals is to enable the federal government to determine the demographic or population structure of the country. Quebec, more than the other provinces, has its own immigration regime, in legislative terms, stemming from this Act and based on an agreed division of labour with the federal government in which the province is responsible for selection of immigrants to its province (e.g. enrichment of the sociocultural heritage of Quebec, economic benefit and consistency with Quebec's demographic goals), while the federal government preserves overall responsibility for national standards of admission of immigrants into Canada, including in respect of screening for national security purposes. Let us say that, on our use of the nomenclature, this agreed division of labour between the federal government and Quebec on immigration, being little susceptible to change (in general terms), has effective quasi-constitutional status. ${ }^{126}$

Even with the sui generis Quebec immigration arrangement, the federal government has uncontroversial constitutional capacity to determine the

125 Section 91(25) of the 1867 relates to naturalization and aliens. This is a rather idiosyncratic head of power in the sense that little has been legislated on its basis, and, as a consequence, there has been little litigation in respect of it. The Citizenship Act arguably falls under this section.

126 Strictly speaking, the federal government has formal agreements with each of the provinces on immigration, pursuant to section 8(1) of the Immigration and Refugee Protection Act [and also section 5(1) of the Department of Citizenship and Immigration Act]. These agreements include provisions for provincial nominees - a class of immigration that is fast growing in importance. However, the Canada-Quebec regime is strategically sui generis in respect of the degree to which it transfers upstream policymaking powers (i.e. selection and admission) to the province, as well as the degree to which it has as one of its express objectives the preservation of the demographic weight of Quebec within Canada. 
aggregate number or quantum of immigrants entering Canada, as well as the rate of such entry; and, as a consequence, given the necessary census or statistical data, the net rate of growth of the Canadian population resulting from immigration. That the federal government may therefore choose to grow the aggregate Canadian population in order that it reach a certain threshold of strategic moment is beyond constitutional reproach.

Evidently, in purely practical terms, mass increases to immigration levels do not come without concrete policy-political costs, including significant additional upstream costs related to increased security and quality screening, as well as downstream costs relating to integration and social services. In particular, any increase in aggregate immigration to the country would likely have to be in keeping with the Canada-Quebec Accord of 1991 on immigration. One notable objective of the Accord, as stated in section 2, is to preserve the demographic weight of Quebec within Canada and to integrate immigrants to Quebec in a manner that respects the province's distinct identity. To the extent that we see this Accord as quasi-constitutional, we can see it as materially complicating the otherwise uncontroversial constitutional capacity of the federal government to increase Canada's overall population-whether or not such demographic increase is conscientiously aimed at bolstering national strategic power. Although the wording in the Accord is not tantamount to a guarantee, it would seem reasonable to expect that the annual growth in Canadian immigration would in practice be capped less by the global supply of immigrants than by the global supply of immigrants susceptible to integration into Quebec society as a proportion of the total global supply of immigrants. [Section 12(c) of the Accord states that Canada shall not admit any immigrant into Quebec who does not meet Quebec's selection criteria.]

What of the 'quality' of the immigrants Canada may select - that is, the ability or 'talent' of immigrants, even over time and through offspring, to directly increase the potency of the strategic instruments of the state or the underlying factors of strategic power? Prima facie, there is nothing barring the federal government, in constitutional terms, from determining the quality of the immigrants entering Canada, something it currently does through the various classes of immigration in the Immigration and Refugee Protection Act. It follows that in the event that the federal government were interested in a particular immigrant or immigrant group 
(say, for strategic reasons), there would be no constitutional bar to that particular immigrant or group being specifically targeted and recruited by the government-even, of course, if this meant the alteration of existing classes of immigration in statute, or the creation in statute of new classes of immigration. Of course, such recruitment of talent by the federal government would need to be consistent with the said Canada-Quebec Accord.

One additional, constitutionally relevant key driver of strategic power in respect of the population factor, as mentioned, is that of demographic distribution. Massively increased numbers of immigrants would arguably bring greater strategic (and indeed social) benefit to the country if properly and deliberately distributed across the country's physical territory. ${ }^{127}$ As mentioned above in this section, such distribution could at minimum serve to create critical economic masses in cities (and indeed more cities), and assert sovereignty-including through the military instrument-in underpopulated parts of Canada's huge geography, such as the North, the Maritimes and the Prairie provinces. Manifestly, though, such talk raises the vexed question of whether the federal government could meaningfully control the distribution of immigrants - as a shorthand, effectively, for strategically controlling, over time, the distribution of its aggregate population.

A federal requirement of immigrants to live in area $x$ (as opposed to area $y$ ) of the country for a period of time $(\mathrm{t}>0)$ could well be a prima facie affront to the mobility rights in section 6 of the Charter. (Section 6 rights, let us recall, are inured against the notwithstanding clause in section 33.) Indeed, there has to date been no jurisprudence on this very fact pattern to guide us (and precious few section 6 cases at the Supreme Court altogether), so our analysis will have to be largely counterfactual. We know section 6(2) states that every citizen and permanent resident of Canada has the right (a) to move to and take up residence in any province;

${ }^{127}$ This is perhaps a rebuttable presumption. One asks why France and the United Kingdom have only, say, two very large cities for population bases of around 60 million each. One could respond to this, arguendo, by suggesting that physically vast, populous and indeed strategically powerful countries like Russia, the United State and China, by contrast, all have at least half a dozen very major urban-cum-industrial centres spread across their respective territories. 
and (b) to pursue the gaining of a livelihood in any province. Furthermore, the rights in section 6(2) are subject to the limitations in section 6(3); that is, (a) any laws or practices of general application in force in a province other than those that discriminate among persons primarily on the basis of province of present or previous residence; and (b) any laws providing for reasonable residency requirements as a qualification for the receipt of publicly provided social services. Finally, section 6(4) provides that none of the above precludes any law, programme or activity that has as its object the amelioration in a province of conditions of individuals in that province who are socially or economically disadvantaged if the rate of employment in that province is below the rate of employment in Canada.

Would the said (re)distribution requirement in respect of immigrants be constitutional? Were the required distribution or redistribution in question strictly intraprovincial (say, from big city $a$ to smaller city $b$ in the same province), rather than interprovincial, then there would be no breach of section 6 rights. The question of constitutionality would turn on whether the enacting government was justified on the basis of the division of powers scheme in the 1867 Act. In the event, were the federal government the enacting party, what head of power would be availed it? As established several times over in this paper, the 1867 Act is silent on the question of 'strategy' per se. The federal government could not therefore argue before the courts that it is interested in redistributing masses of people (in the event, immigrants) for purposes of growing its strategic power. (This brings us to a crucial point that is woven throughout this paper-to wit, could the courts ever fathom recognizing 'strategy' as a proper end of the state? We take this up very soon below.) A possible alternatives could consist in the use of the federal POGG power-in particular, the residual branch as it relates to national security, or, more precisely, say, sovereignty. Still, this rationale is unlikely to be credible before the court. A far more likely scenario, sub-constitutionally, is that the federal government would have to strike an agreement with a province-the proper enacting party for matters within the province-to require such intraprovincial distribution of immigrants. (The federal government could, of course, arguably go it alone if there were a question of distributing immigrants within or indeed between any of the three federal territories.) 
Naturally, talk of strict intraprovincial or intraterritorial distribution of population (especially immigrants) must struggle with the possibility that immigrants may simply, of their own volition, jump from province to province (or territory, or from territory to province), as is their prima facie constitutional right - at least insofar as the taking up of residence or the pursuit of a livelihood is concerned. ${ }^{128}$ In this case, one might observe that section 6(2) refers only to citizens and permanent residents, and not to aspiring immigrants who are not yet permanent residents-technically, foreign nationals. Thus it is conceivable that the federal government, should it wish to do so, could easily impose certain residency conditions on foreign nationals pending, or as a condition of, their receipt of permanent resident status in order to populate areas of strategic interest for the state. (Of course, on the current practice, leaving aside policy-political costs, this does not leave much time - a few years on average-for the foreign national to actually reside in his or her designated location before possibly acceding to permanent resident status; although, indeed, the period preceding accession to permanent resident status could well be increased in law or regulation.) Moreover, as per the ruling in Canadian Egg Marketing Agency v. Richardson ${ }^{129}$, the designated residency requirement could theoretically be applied to even permanent residents and citizens if, as per section 6(3), the mobility discrimination against the individual in question is not primarily on the basis of residence. In this sense, the majority of the Supreme Court in Canadian Egg held that sections 6(2) and 6(3)(a) should be read as a single right, stating:

Section 6 of the Charter guarantees the mobility of persons, not as a feature of the economic unity of the country, but in order to further a human rights purpose. It is centred on the individual. Section 6 relates to an essential attribute of personhood that mobility in the pursuit of a livelihood will not be prevented through unequal treatment based on residence by the laws in force in the jurisdiction in which that livelihood in pursued. Given this purpose, the focus of

\footnotetext{
${ }^{128}$ Provinces and territories are one and the same thing for purposes of the application of Charter rights, as per section 30 of the Charter.

${ }^{129}$ Canadian Egg Marketing Agency v. Richardson, [1998] 3 S.C.R. 157.
} 
the analysis in s. 6 is not the type of economic activity involved, but rather the purpose and effect of the particular legislation, and whether that purpose and effect infringe the right to be free from discrimination on the basis of residence in the pursuit of a livelihood.

The Court, building on this logic, determined that, to the extent that the mobility discrimination in question is legitimately-indeed, primarilypremised on a constitutional head of power, and not residence, a limitation on mobility would be constitutional. Of course, this begs the same question as above: could the federal government argue that strategy is a legitimate purpose, in constitutional terms? Or could it, more or less 'colourably,' offer cognate justifications rooted in, say, a national security or even economic premise?

The pure strategic justification or line of constitutional defence, on section 6 grounds, for such a distributive scheme would seem rather improbable, given the general and indeed wholly explicable domestic orbit in which Canadian constitutional jurisprudence and scholarship have developed. (That said, perhaps an ostensibly colourable national security or economic line or argument could work: The North needs more people to secure the Arctic against foreign encroachments, given climate change - to take but one example that may be 'low-hanging fruit.') And this therefore leaves us with only section 1 of the Charter as a possible 'saving clause' for the apparent breach of section 6 rights that would be caused by any forced or required (re)distribution of Canadian citizens or permanent residents for primarily strategic reasons. Section 1, of course, "guarantees the rights and freedoms set out in it subject only to such reasonable limits prescribed by law as can be demonstrably justified in a free and democratic society." This provision is famously adjudicated by the Oakes test, ${ }^{130}$ in which Chief Justice Dickson set out a four-part test for determining what in fact were these soi-disant "reasonable limits." Justice Dickson said that an impugned provision could be saved under section 1 if there were proof of a pressing and substantial objective; a rational connection between the provision and the objective; minimal impairment of an individual's rights and freedoms; and a predominance of

${ }^{130}$ R. v. Oakes, [1986] 1 S.C.R. 103. 
benefits from the said provision vis-à-vis the negative impact on the associated rights. These considerations are patently domestic in their concern. They ignore strategy as a legitimate end of the Canadian state, evidently even in the said context of (the values of) a "free and democratic society." And yet the jurisprudential record in respect of Oakes, while inconsistent and non-uniform, suggests that a limitation on mobility rights, even for strategic purposes, if reasonably presented, could well be justified as pressing and substantial (first branch of the Oakes test), a standard on which the courts are usually very deferential to the government. The limitation might also pass the second branch-that of rational connection, even if a domestically-focused court would be hard-pressed to be persuaded of the rational connection in policy between population distribution and strategic weight. ${ }^{131}$ However, where the limitation would likely falter is at the third branch of the test-that of minimal impairment, upgraded in later jurisprudence to an impairment that is as little "as reasonably possible."132 It stands to probable reason that the courts would strike down the limitation as not being the best among more reasonable alternatives for growing the strategic might of the state-constitutionally legitimate alternatives the permutations of which are discussed throughout this piece. Of course, some of these alternatives, depending on the factor or element of power to which they relate, are, as it were, more strategic than others - and this line of reasoning suggests that the courts, despite the absence of any such tradition, would be somewhat knowledgeable in respect of, or 'culturally' attuned to considerations of strategy.

\section{CONCLUSION}

Canada has a Strategic Constitution. The Canadian Constitution, despite its manifestly astrategic conception, can in general terms be

${ }^{131}$ In "So What is the Real Legacy of Oakes? Two Decades of Proportionality Analysis Under the Canadian Charter's Section 1” (2006) 34 Sup. Ct. L. Rev. 501, Sujit Choudhry interestingly notes the necessary privileging of empirical social science or policy evidence in the context of the Oakes test-a hurdle over which strategic considerations would be hard-pressed to jump.

${ }^{132}$ Edwards Books \& Art Ltd. v. R., [1986] 2 S.C.R. 713. 
employed with great flexibility by a given government, should the requisite strategic policy acumen and political will be there, to project significant power through the state's diplomatic and military instruments - directly or through the mediation of the said factors of strategic power. In and of themselves, Canada's diplomacy and military, as both elements and instruments of power, are, with only a few exceptions, largely untrammelled, in constitutional terms-rooted as they are in the royal prerogative. These instruments are in turn supported by a number of critical elements or factors of power, each of these with its particular constitutional limitations, in most cases related to the federal division of powers (textual and jurisprudential), and in a few cases occurring as a result of Charter limitation. In the aggregate, however, the picture painted in this piece is of a Canadian Constitution that does not, in principle, inhibit considerable strategic action by the state-again, even if such strategic action was not envisioned by the Fathers of Confederation and subsequent constitutional draftspersons, and even if such strategic action is little explored (and indeed understood) in our country's constitutional jurisprudence. This is not an unremarkable paradox. Indeed, one observes, arguably, with some of the pronouncements and moves made by the last Harper government (in particular in respect of Afghanistan and the military), that such strategic intent, whatever one makes of the particular virtues of the strategic ends pursued, may, to some extent, be crystallizing. If this be the case, the Constitution will not inhibit it, and will in many cases aid it - even if the road be on occasion indirect or tortuous. 